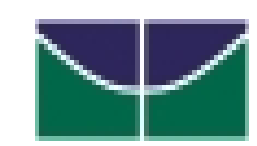

Universidade de Brasília

Centro de Excelência em Turismo

\title{
A CACHAÇA COMO IDENTIDADE CULTURAL
}

\author{
Patrícia Cristina Leite Feitosa
}

Orientadora: Wilma Maria Araújo Coelho

\begin{abstract}
Monografia apresentada ao
Centro de Excelência em Turismo da Universidade de Brasília como requisito parcial para a obtenção do certificado de Especialista em Turismo, Cultura e Lazer.
\end{abstract}

Brasília - DF, Abril de 2005. 


\section{Universidade de Brasília \\ Centro de Excelência em Turismo}

Curso de Especialização em Turismo, Cultura e Lazer

\section{A CACHAÇA COMO IDENTIDADE CULTURAL}

Patrícia Cristina Leite Feitosa

Banca Examinadora:

Prof.(a): Wilma Maria Araújo Coelho (orientadora)

Prof(a): Dulce Suassuna

Brasília, Abril de 2005 
Universidade de Brasília

Centro de Excelência em Turismo

Curso de Especialização em Turismo, Cultura e Lazer

\title{
A CACHAÇA COMO IDENTIDADE CULTURAL
}

\author{
Patrícia Cristina Leite Feitosa
}

Banca Examinadora:

Prof.(a) Orientadora: Wilma Araújo

Prof.(a): Dulce Suassuna

Brasília, Abril de 2005 


\section{DEDICATÓRIA}

Dedico este trabalho ao meu namorado, Cláudio Eduardo da S. Nóbrega, por sua dedicação, apoio, carinho, pelo incentivo e encorajamento nos momentos de angústia e, principalmente, pela paciência no período da realização deste. 


\section{AGRADECIMENTOS}

À Deus, pela força e sabedoria.

Aos meus pais, que contribuíram para a realização de mais um sonho.

À minha irmã, Priscila, pela colaboração.

Ao meu avô, General, pelas longas conversas sobre cachaça.

À Profa Dulce Suassuna e à Profa Wilma Araújo, pela atenção e orientação.

E a todos que de alguma forma colaboraram direta ou indiretamente. 


\section{RESUMO}

Este trabalho apresenta o conceito e a classificação da cachaça, assim como suas formas de produção, especialmente a forma artesanal. Apresenta a bebida como identidade cultural do povo brasileiro, relacionando-a ao folclore, às festas populares, ao futebol e à religião. Refleti no decorrer do curso, sobre a dificuldade de se encontrar no mercado obras sobre a relação da cachaça com a cultura. A intenção não é chegar perto das grandes obras sobre cachaça, às quais devo o pouco que conheço. $O$ intuito é singelo: tratar os tópicos com a maior objetividade possível, conferindo uma abordagem voltada para a cultura contida na bebida. Identifico a origem e descrevo os rótulos, que são instrumentos de manifestação dos sentimentos que consagram o consumo da cachaça.

Palavras-chave: Cachaça, Identidade Cultural, Folclore, Festas Populares e Futebol. 


\begin{abstract}
This work presents the concept and the classification of the white rum, as well as their production forms, especially the craft form. It presents the drink as cultural identity of the Brazilian people, relating them to the folklore, to the popular parties, to the soccer and the religion. I contemplated in elapsing of the course, about the difficulty of finding in the market works about the relationship of the white rum with the culture. The intention is not to arrive close to the great works on white rum, to which I owe the little that I know. The intention is simple: to treat the topics with the largest possible objectivity, checking an approach gone back to the culture contained in the drink. I identify the origin and I describe the labels, that are instruments of manifestation of the feelings that consecrate the consumption of the white rum.
\end{abstract}

Key-word: White rum, Cultural Identity, Folklore, Popular Parties and Soccer. 


\section{LISTA DE FIGURAS}

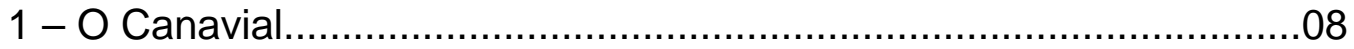

2 - Fermentação do caldo de cana...............................................09

3 - Destilador de Cobre..............................................................11

4 - Ruínas do Engenho dos Erasmos........................................15

5 - Planta em perspectiva da Casa Grande.....................................17

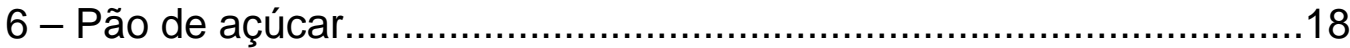

7 - Pedra de mó e energia humana para extração do caldo de cana....19

8 - Corte de cana-de-açúcar...................................................20

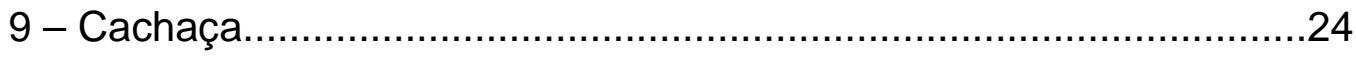

10 - Feijoada e caipirinha .......................................................... 


\section{LISTA DE QUADROS}

1 - Terminologias usadas para cachaça.....................................26 


\title{
LISTA DE SIGLAS
}

\author{
ABRABE - Associação Brasileira de Bebidas \\ AMPAQ - Associação Mineira dos Produtores de Cachaça de Qualidade \\ FENACA - Federação Nacional das Associações dos Produtores de Cachaça de \\ Alambique \\ IPHAN - Instituto do Patrimônio Histórico e Artístico Nacional \\ OMC - Organização Mundial do Comércio \\ PBDAC - Programa Brasileiro de Desenvolvimento da Cachaça
}




\section{SUMÁRIO}

RESUMO............................................................................................................

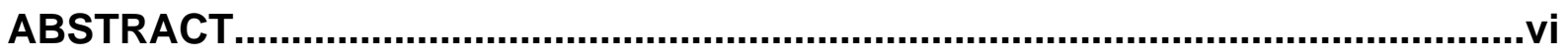

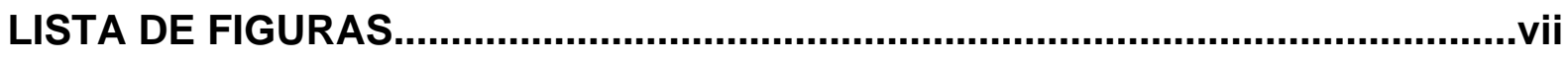

LISTA DE QUADROS.................................................................................viii

LISTA DE SIGLAS..............................................................................................

INTRODUÇÃO............................................................................................1

1 CACHAÇA: SÍMBOLO DE IDENTIDADE NACIONAL..................................4

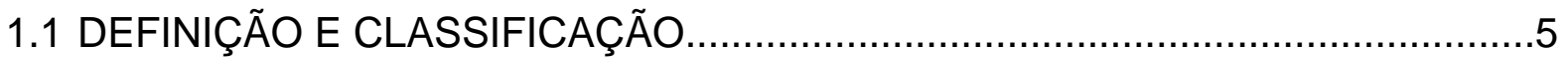

1.2 Etapas para a produção......................................................................

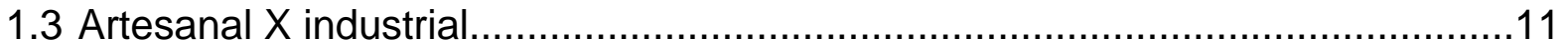

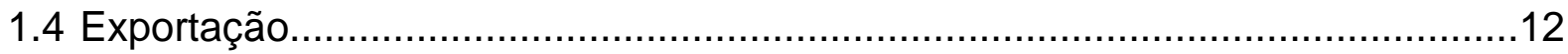

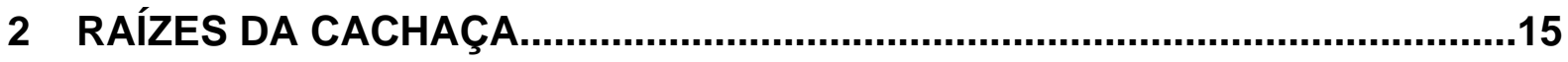

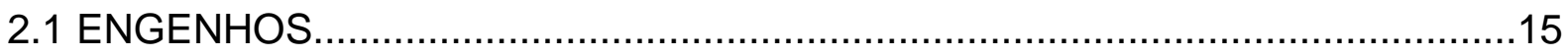

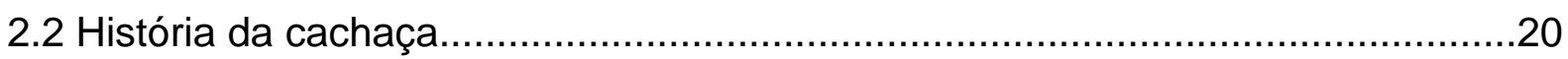

3 CACHAÇA E CULTURA

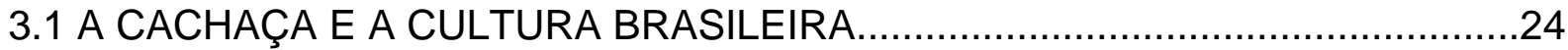

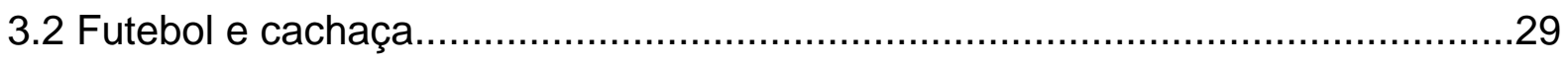

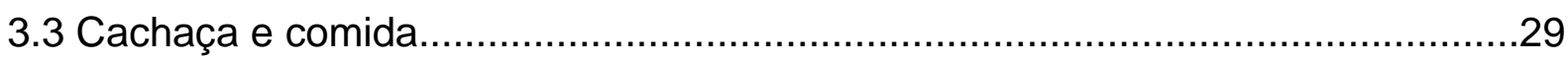

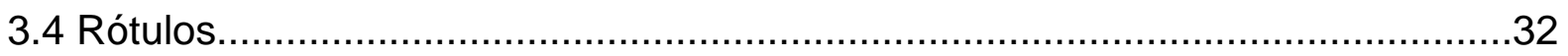

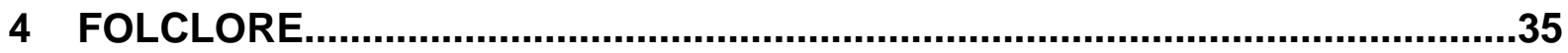

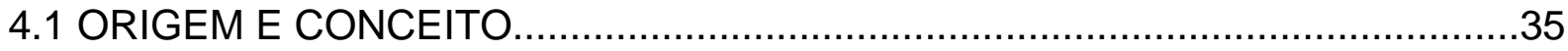




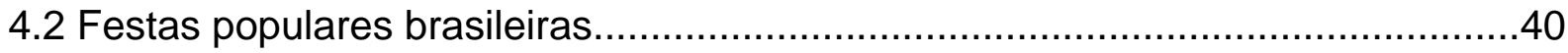

CONSIDERAÇÕES FINAIS..........................................................................43

REFERÊNCIAS BIBLIOGRÁFICAS.............................................................45

APÊNDICE A.........................................................................................47

APÊNDICE B.............................................................................................48

APÊNDICE C.................................................................................................... 49

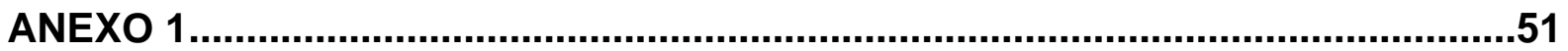

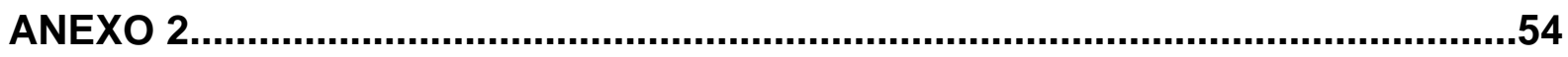

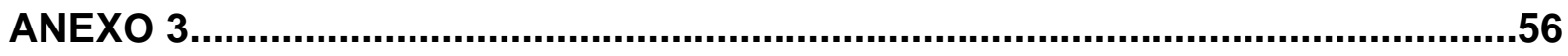




\section{INTRODUÇÃO}

A relação entre a cachaça e a cultura está presente nas ricas manifestações folclóricas e artísticas do Brasil. Destilada do puro caldo da cana-de-açúcar que the dá sabor e aroma únicos, a cachaça condensa a imensa capacidade de combinação da bebida com os sentimentos de devoção e alegria, as melhores sínteses da cultura brasileira.

Pode-se afirmar que cada povo, ao longo de sua história, escolheu a sua bebida nacional a partir das matérias primas que dispunham para produzi-las. No Brasil colonial o povo criou sua bebida junto às imensas plantações de cana-deaçúcar.

No Brasil a cachaça é a segunda bebida mais consumida, gerando com sua produção, aproximadamente 450 mil empregos diretos e indiretos (Câmara,2004).

Atualmente o governo almeja convencer a Organização Mundial do Comércio (OMC) de que a cachaça é um produto único e típico brasileiro, como a champanhe é da França. Aos demais países, solicitará que reconheçam a denominação cachaça. Em troca, regularizará os direitos de seus produtos no Brasil.

A elaboração deste trabalho deve-se à importância da identidade cultural da cachaça para o povo brasileiro. Devido a escassez de trabalhos científicos na área, o objetivo específico deste é analisar sua origem, a legislação pertinente e, o modo de produção, artesanal em especial.

A pesquisa, com abordagem qualitativa, seguiu com as seguintes etapas: 1) Pesquisa bibliográfica e documental, sendo realizado um levantamento de livros e documentos pertinentes ao tema, especificamente livros de leitura corrente, como as obras de divulgação (conhecimentos científicos) e literárias (cantigas); livros de referência remissiva, que remetem a outras fontes e, informativa, por aduzir a informação que se busca. $\mathrm{Na}$ investigação documental, as principais fontes foram jornais, folhetos, revistas e matérias divulgadas na Internet; 2) Trabalho de campo, no qual foi aplicado um questionário (Apêndice $A$ ) com questões abertas, fechadas dicotômicas e de múltipla escolha, acerca do caso estudado para, em seguida, mediante análise de conteúdo, obter as conclusões. A população alvo foi constituída 
por vinte e três estudantes de Pós Graduação da UnB, por apresentarem significativo nível de instrução cultural e por pertencerem a diversas classes sociais. O benefício foi a obtenção de elementos que agregaram conhecimento direto da realidade por meio de opiniões e comportamentos.

A análise dos dados coletados foi realizada por meio de uma tabulação (Apêndices B e C). Com relação às perguntas abertas, sintetizei as informações, tratando das mesmas no decorrer do trabalho. Houve uma análise descritiva e exploratória. Descritiva, por retratar as características da bebida cachaça e o estabelecimento da relação entre a mesma e a cultura popular. Exploratória, por proporcionar maior conhecimento sobre a bebida, com vistas a tornar mais explícita sua relação com a cultura.

Em relação à base teórica, foram relevantes os trabalhos de Araújo (1997), Brunhs, Feijó (2001) e Laraia (2001) para a compreensão da cachaça e sua importância na construção da identidade nacional.

Alguns autores tratam da cachaça associando-a a outros elementos da cultura brasileira, como por exemplo, Brunhs, que abordou a história do futebol brasileiro apresentando sua relação com a cultura, detalhando suas fases, desde a criação até a popularização do esporte. Considerado paixão nacional, o futebol mantém afinidade com a bebida. O trabalho deste autor favorece a fundamentação dessa afinidade, sendo fonte de referência informativa na busca por relações culturais, assim como Laraia (2001). Este autor, que faz uma pormenorização dessas relações culturais, desenvolvendo o conceito de cultura, mostra como ela influencia a humanidade, e a existência de uma grande diversidade cultural em um mesmo ambiente.

Alia-se, neste caso, a compreensão de Lima (1999) que conceitua e descreve a origem do folclore. Consulta necessária para embasar esta monografia na relação dos costumes tradicionais com a bebida, que é melhor descrita na obra de Feijó(2001). Ela diferencia a cachaça artesanal da industrial, ressaltando que o processo artesanal só utiliza caldo de cana, enquanto no industrial é feita uma mistura de melaço e aguardente, além de ser acelerado o processo de fermentação por aditivos químicos. Retrata a história com curiosidades, tais como a mudança do nome de uma das cachaças artesanais mineiras mais famosas, a Havana. Após um litígio na justiça, desde maio de 2001, essa cachaça foi renomeada como Anísio 
Santiago. Suas características se mantiveram: produção reduzida e sem substâncias químicas.

A compreensão dessas obras propicia a elucidação do problema que se propõe: Qual é a representação social da cachaça para o povo brasileiro?

No primeiro capítulo deste trabalho, define-se e classifica-se a bebida, abordam-se as etapas de produção, as diferenças entre a artesanal e a industrial e dados sobre sua exportação.

No capítulo seguinte, discorre-se sobre os engenhos e suas instalações, ressaltando o prelúdio da cachaça.

No terceiro capítulo, analisa-se a relação da bebida com a cultura brasileira e faz-se um breve relato sobre os rótulos de algumas cachaças.

No último, parte-se do conceito de folclore para reforçar a relação entre cachaça e identidade nacional, e faz-se um estudo da inserção da cachaça nas festas populares brasileiras, especialmente no carnaval e nas festas juninas. 


\section{CAPÍTULO 1 \\ Cachaça: Símbolo de identidade nacional}

A cachaça foi por muito tempo pejorativamente tratada como bebida de negros, devido principalmente à sua origem nos engenhos de açúcar do período colonial, em que era largamente consumida pela população escrava.

Ainda no período colonial, o tráfico de escravos impôs a valorização contínua da aguardente, pois esta era indispensável na compra do negro africano, moeda sem embargo. O vinho de Portugal, tão apreciado até então e cuja exportação ia aos poucos diminuindo, começou a sentir as conseqüências da preferência popular pela aguardente de cana-de-açúcar brasileira.

A Companhia de Comércio, monopolizadora dos transportes entre as colônias, a Metrópole e a Europa recorreu à ciência do Conselho da Coroa. O meio encontrado pelo Conselho para superar o problema da queda nas exportações do vinho de Portugal foi desastroso para a cachaça brasileira: por meio da Carta Real, de 13 de Setembro de 1649 proibiu-se a fabricação da aguardente em todo o Brasil (Cascudo,1968). Os prejudicados reagiram imediatamente. Passou-se a produzir a aguardente clandestina, para atender a demanda interna e manter ativas as trocas no mercado de escravos africanos.

O impedimento para a produção e a comercialização da cachaça perdurou por cento e vinte e quatro anos. Nesse período, várias revoltas populares aconteceram em todo o Brasil em favor do direito de produzir, vender, comprar e exportar a cachaça. A de maior importância foi a Revolta da Cachaça ou Bernarda, que aconteceu no Rio de Janeiro entre Novembro de 1660 e Abril de 1661. Cento e doze senhores de engenho não aceitaram a proibição e, unidos, depuseram o governador da capitania e derrubaram a proibição.

Com a acentuação do comércio de escravos, houve um aumento do comércio da aguardente brasileira.

A consciência nacional foi se definindo à medida que setores da sociedade colonial passaram a identificar nela a fonte de seus problemas. 
Mesmo com a presença relevante em importantes momentos da vida nacional, e apesar do lugar que ocupa no imaginário e no cotidiano do povo brasileiro, a cachaça ainda é vítima de um certo desnivelamento no que diz respeito ao seu prestígio social. O mais famoso e autêntico destilado brasileiro ainda tem sua circulação praticamente circunscrita a vendinhas obscuras, botecos e bares suburbanos. Mas sua presença é forte e persistente, enraizada na vida do país desde o seu nascimento.

Durante algum tempo, entre os séculos XIX e XX, a cachaça deixou de ser símbolo de nacionalismo. Momento de crise de identidade, em que a bebida perdeu terreno. Somente em 1922, com o Movimento Modernista, começou a recuperação do sentimento de brasilidade em todos os segmentos culturais (Lima, 1999).

O folclorista Mário Souto Maior (1970), grande conhecedor e apreciador da cachaça, observa que ela era apenas um veículo simplificador para fundir os extremos na equação: desejo idealizado e realização sonhadora.

\subsection{Definição e classificação}

De acordo com o artigo 92, do Decreto Presidencial № 4851, de 2 de outubro de 2003:

"Cachaça é a denominação típica e exclusiva da aguardente de cana produzida no Brasil, com graduação alcoólica de 38 a $48 \%$ em volume, a $20^{\circ}$ Celsius, obtida pela destilação do mosto fermentado de cana-de-açúcar com características sensoriais peculiares, podendo ser adicionada de açúcares até seis gramas por litro, expressos em sacarose".

Segundo Marcelo Câmara (2004:26),

"a cachaça é a aguardente de cana-de-açúcar que pinga na ponta do alambique, é a bebida nova, branca, fresca, virgem, transparente, feita do coração (do meio) do destilo, desprezados a cabeça e o rabo ou cauda da 
destilação. Cachaça é bebida nova, sem envelhecimento, quando muito apenas descansada, repousada, guardada, no máximo, três meses, em madeira quase neutra, capaz de não alterar as suas características de cor, aroma e sabor, antes de ser engarrafada".

Para Feijó e Maciel (2001), a cachaça é classificada de acordo com seu processo de fabricação, que pode ser o industrial ou o artesanal.

A cachaça industrial não é obtida em alambiques, mas sim em equipamentos destinados à produção do álcool, chamados de colunas industriais de destilação ou colunas contínuas de destilação. $\mathrm{Na}$ indústria, trabalham-se grandes volumes de caldo de cana, que, depois de fermentados, são destilados, obtendo-se milhares de litros de cachaça por dia, tudo automatizadamente. Na pesquisa realizada para este trabalho, verificou-se que $100 \%$ dos indivíduos questionados têm consciência de que a cachaça é obtida através da fermentação da cana de açúcar. Dessa população, $61 \%$ é do sexo feminino.

As aguardentes, normalmente, são de custo baixo, devido à imensa capacidade de produção das indústrias. Os grandes volumes fermentados são integralmente destilados, não sofrendo nenhum tipo de separação das partes, como ocorre com a cachaça artesanal.

Um processo muito comum que acontece com a cachaça industrial é a padronização, que consiste na mistura de diversas aguardentes compradas de diferentes produtores. Essa mistura é uniformizada através de retificadores, que enquadram os componentes químicos da bebida nos parâmetros e limites estabelecidos na legislação, como graduação alcoólica, acidez, aldeídos, presença ou não de álcool metílico, metanol e outros. O aproveitamento total do volume fermentado para a destilação e a padronização não permite que o produto obtido se destaque em termos de qualidade sensorial, por não apresentar aroma e gosto agradáveis, sendo alvo de críticas por consumidores que passam da segunda dose. O grande desafio da indústria é aprimorar a estrutura organoléptica do seu produto, dar-lhe perfume e sabor, para que ela fique tão atraente quanto a cachaça artesanal, que apresenta o aroma típico da cana-de-açúcar.

Geralmente, as indústrias não possuem plantações próprias e para a moagem utilizam a cana-de-açúcar de diferentes procedências, possivelmente com variações na sua composição que vai assim influenciar as características da cachaça. 
A cachaça artesanal é fabricada em alambiques e é produzida em pequenos volumes. O alambique é operado manualmente pelo aguardenteiro. Ao contrário das indústrias, os engenhos possuem a sua própria roça de cana-de-açúcar, cuja produção é toda destinada à fabricação da bebida. Existem poucas e, ao mesmo tempo, milhares de maneiras de fazer cachaça artesanal. São pequenas as variações entre as regiões brasileiras.

Cada alambiqueiro, além de seguir a tradição da família ou da região, tem os seus segredos, detalhes nos processos de transformação que não são revelados, ficam retidos e são desenvolvidos no núcleo da família. Fazer cachaça é, ao mesmo tempo, ciência, arte, paixão e sabedoria. Tudo é feito com muita calma, cuidado.

Além dos pequenos volumes a serem trabalhados, sua principal característica é o tempo de produção. Os processos de fazer e as reações químicas necessárias para desenvolver os componentes do sabor e do aroma, ocorrem sem pressa, no ritmo da vida.

$\mathrm{Na}$ fabricação da cachaça artesanal, não entram elementos químicos artificiais, agressivos, estranhos ao universo da cana-de-açúcar, que possam modificar os caminhos para um nascimento natural da cachaça.

Há quatro tipos de cachaça artesanal, segundo Câmara (2004:60): a pinga nova (com até 3 meses de descanso), a envelhecida (no mínimo 1 ano em tonel de madeira), a matizada (mistura da nova com a envelhecida), e a reserva especial (no mínimo 3 anos em tonel de madeira).

\subsection{Etapas para a produção}

Tudo começa com a escolha da variedade de cana a ser plantada em solo fértil. Na época atual, as variedades mais recomendadas são híbridas, resultantes do cruzamento de espécies seculares e de seus descendentes, que tiveram fama na agricultura e folclore brasileiros, como a cana crioula da Madeira, a primeira que chegou ao Brasil. Recomenda-se que o corte da cana seja feito no inverno. 
De acordo com Maya (2002), as etapas para a produção da cachaça artesanal são as seguintes:

- Colheita da cana-de-açúcar;

- Transporte da cana colhida;

- Moagem da cana;

- Filtragem do caldo;

- Diluição;

- Fermentação;

- Pré-aquecimento;

- Destilação;

- Armazenagem;

- Envase;

- Rotulagem.

O corte correto da cana madura, no tempo certo, na roça que não sofreu queima, é o primeiro passo no processo de fabricação da cachaça artesanal (Figura 1). O cuidado e a limpeza no transporte da colheita fazem com que a cana chegue à moenda madura, fresca e limpa para ser esmagada. Dentro de no máximo 24 horas, a cana deverá ser moída, para que não haja perda do teor de açúcar e aparecimento de fungos e outros microorganismos.

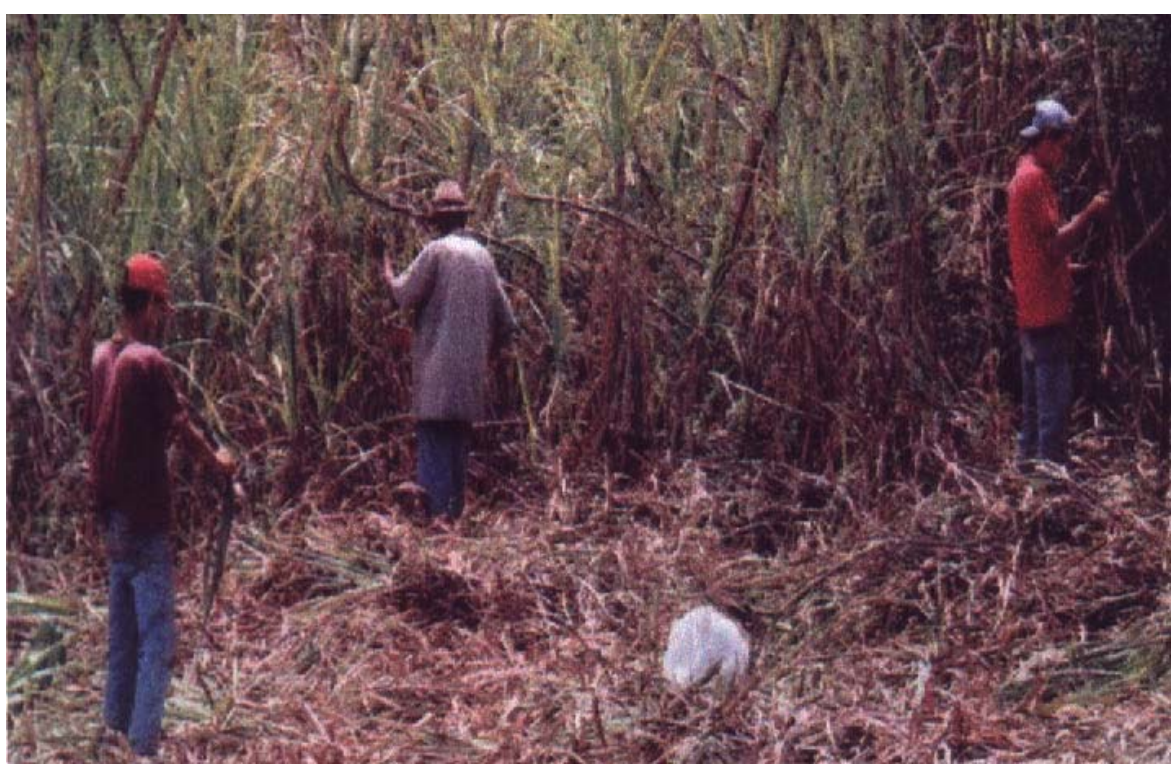

Figura 1: O canavial (Revista Gula - maio 1998:52) 
Da moenda, sempre limpa, jorrará o caldo da cana. Coado em uma peneira fina, ele irá decantar em tanques para eliminação de terra, areia, bagacilhos e outros sólidos indesejáveis.

A preparação do mosto consiste em dar ao caldo, através de água limpa e potável, níveis ideais em termos de sacarose e acidez, a fim de que a etapa seguinte, a fermentação, certamente a mais importante, se processe em boas condições.

Em dornas de madeira ou de aço inoxidável, o mosto passará, sob condições perfeitas de higiene, temperatura, luz e umidade, por um complexo processo químico, que transformará todo o açúcar em álcool etílico. Isso acontecerá, quando for adicionada ao mosto, uma levedura, ou fermento, a fim de que ela atue com eficácia. O fermento pode ser químico, industrial, fabricado no próprio engenho, ou natural, feito com bagaço de cana, milho maltado, farelos de milho, de arroz ou soja. São vários os tipos de fermento: prensado, granulado seco, selecionado, misto, caipira e outros.

Na fermentação o mais importante é conseguir o máximo de álcool possível, e evitar outros tipos de fermentação, como a acética (vinagre) ou bútrica (ácido bútrico), que deixa a cachaça com uma acidez incorreta e indesejável. No período máximo de 36 horas, a fermentação, requerendo um controle muito atento do alambiqueiro, transformará o mosto em álcool e gás carbônico (Figura 2). Com isso, surge o vinho de cana, ao qual o povo chama desde o século XVI, de grapa doida ou grapa azeda, que virou sinônimo de cachaça.

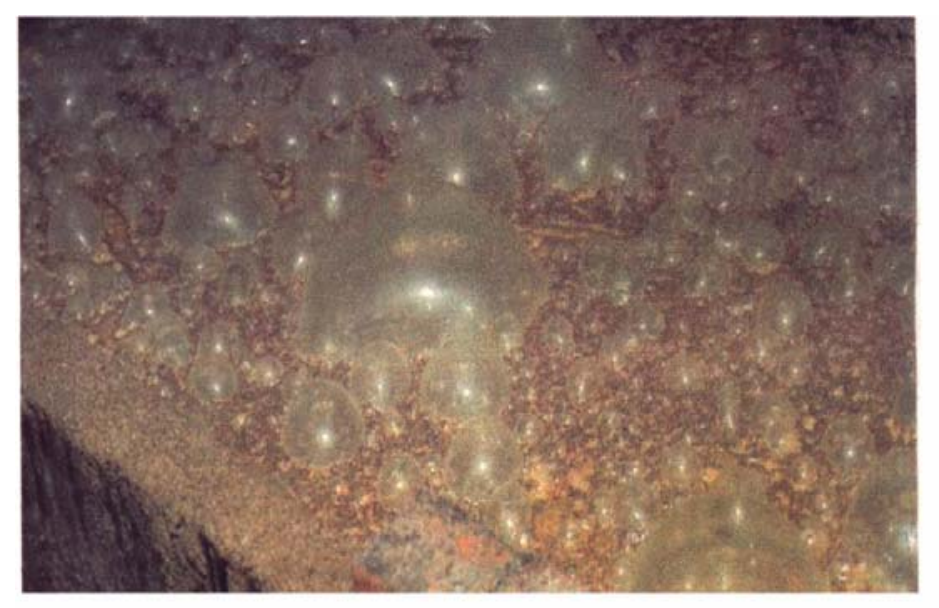

Figura 2: Fermentação do caldo de cana.

(Carvalho, Murilo e Silva Silvestre, SP - 1947:31) 
Se, na sala de fermentação, houver mal cheiro, odor de vinagre, de leite azedo, ovo podre, e presença abundante de moscas, certamente, alguma coisa foi ou está sendo feita erradamente. É na destilação que surge a pinga.

O vinho é depositado em uma panela ou cebolão, que, sob a ação da caldeira, vai esquentar, ferver, até a evaporação; no capitel ou cabeça, acontece a evaporação; uma coluna conduzirá o vapor do vinho; e num capelo ou refrigerador, o vapor será resfriado pela ação de serpentinas, e condensado; nascendo a cachaça. Cebolão e capitel são chamados de partes ascendentes do alambique; coluna e capelo, de partes descendentes.

Segundo Câmara, "Somente se aproveita o coração do destilo, a parte central da alambicada, considerada nobre e própria para o consumo (...) cabeça e cauda comprometem o sabor da cachaça e prejudicam a saúde do consumidor" (2004: $40,41)$.

Antes de ser armazenada, a cachaça passa por um filtro de carvão vegetal, que retém um possível excesso de cobre da bebida e diminui a sua acidez. Argumenta-se que o cobre contamina a bebida, pois em seu interior, se formam os sais de cobre. E que também é um destruidor da flora natural do intestino, e ao longo prazo, cancerígeno. Devido a esse fato, defende-se a substituição do cobre pelo aço inoxidável no cebolão e nas serpentinas. E sugere-se que seja feita a bidestilação da cachaça, alegando que apenas uma destilação seria incapaz de eliminar todos os elementos nocivos e indesejáveis presentes nela.

Para alguns cachaçólogos (estudiosos de cachaça), a bidestilação descaracteriza a bebida, extrai as peculiaridades da boa pinga, que são o perfume rústico de engenho e o gosto da cana. O primeiro cachaçólogo foi o mineiro João Manso Pereira (1750-1820), professor de gramática e metalurgista, químico autodidata e empírico. O objetivo de seus estudos e projetos era melhorar a composição química de uma cachaça, sem substâncias tóxicas, nocivas, nascidas na destilação.

A cachaça, depois de ter passado pelo filtro de carvão vegetal, será então armazenada em tonéis e dornas. Depois, ela é engarrafada e rotulada, para ser distribuída no mercado; ou então, ela irá repousar, envelhecer, para envase e consumo posterior. 


\subsection{Artesanal $X$ Industrial}

A diferença entre a cachaça artesanal e a industrial está no processo de produção. Artesanalmente, a produção é de batelada. Enche-se o equipamento, destila-se, e depois o esvazia completamente. É produzida em pequenos volumes. As etapas, na produção da cachaça, acontecem sem pressa, no ritmo da vida (Figura 3).

No processo industrial, de coluna, há um volume maior de produção, com fluxo constante, a todo momento, entra por um lado o mosto fermentado, e do outro, sai a cachaça já destilada, acelerando a produção da bebida.

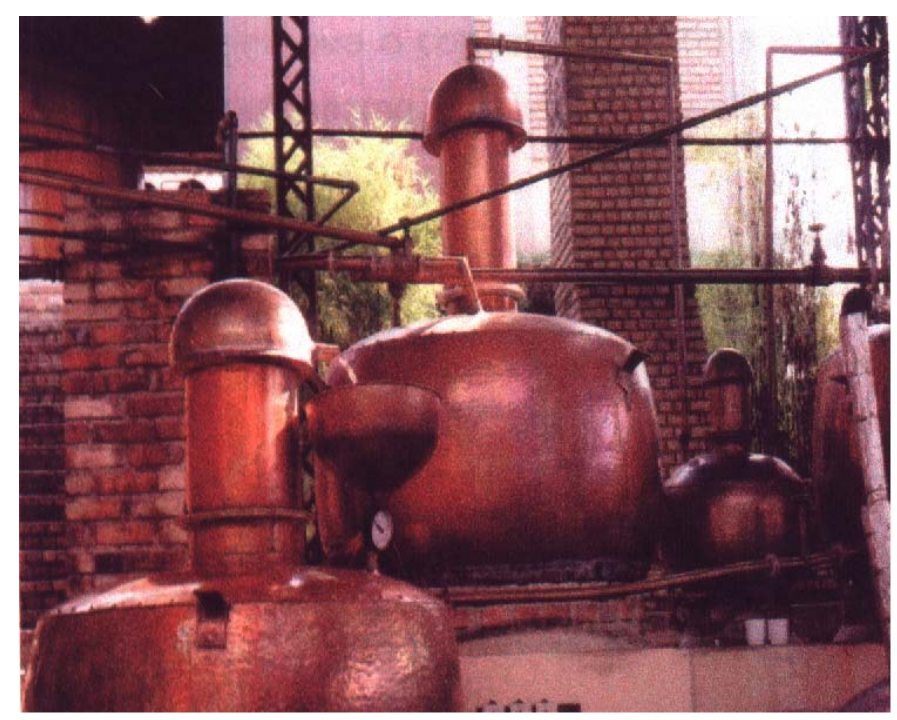

Figura 3: Destilador de Cobre (Revista Gula - maio 1998:53)

A cachaça de alambique pode sim ter uma qualidade um pouco superior às de coluna, desde que tenha um controle de produção e qualidade, o que na maioria dos alambiques espalhados pelo interior do Brasil não acontece.

A principal diferença da cachaça artesanal em relação à industrial está no aroma; enquanto a padronização passa a ser um atributo positivo da cachaça industrial em relação à artesanal, requisito básico para uma bebida de exportação. 
Entretanto, discute-se muito a respeito das diferenças no sabor das cachaças. Algumas pessoas consideram o produto artesanal mais suave, apesar de geralmente ter uma graduação alcoólica mais alta. O que realmente influencia é o envelhecimento da bebida. Normalmente, grande parte das marcas industriais não é envelhecida.

De acordo com o Decreto Presidencial No 4851, de 2 de Outubro de 2003, 0 tempo mínimo para uma cachaça ser considerada envelhecida é de um ano.

\subsection{Exportação}

Apesar da trajetória de quinhentos anos de subalternidade e infâmia, lutando contra o preconceito do poder e das elites, contra a mentalidade colonizada, a cachaça é, hoje, o destilado mais consumido no país e o terceiro mais consumido no mundo. No Brasil, apenas a cerveja, um fermentado, está à frente da cachaça.

Calcula-se que 100 milhões de doses de cachaça são tomadas diariamente das 19 às 21 horas pelo povo trabalhador, como relaxante depois de um dia de trabalho, ou como abrideira para o jantar familiar. No estudo realizado, verificou-se que $39 \%$ dos 23 entrevistados concordam que a cachaça pode ser consumida após o expediente laboral, e $48 \%$ acham que pode ser ingerida antes das refeições. Seu consumo tem periodicidade ocasional, de acordo com 91\% dos mesmos; sendo que, 4\% consomem semanalmente e 4\% mensalmente.

Segundo a Revista Cachaça Magazine (2003), atualmente o Brasil tem quase 4.000 marcas de cachaça no mercado. De acordo com o Programa Brasileiro de Desenvolvimento da Cachaça (PBDAC), a produção anual nacional de cachaça, é de 1 bilhão e 300 milhões de litros. O setor emprega 450 mil pessoas e gera uma receita próxima a 500 milhões de dólares. Desde total, apenas 10\% têm origem artesanal. Minas Gerais é o Estado líder na sua produção, fabricando 200 milhões de litros por ano. Pernambuco, Ceará e Goiás são outros grandes produtores.

Segundo o Ministério do Desenvolvimento, Indústria e Comércio Exterior, em 2003 a indústria da cachaça vendeu 8.200 toneladas da bebida para outros países. 
Em 2004, as exportações do produto cresceram 22\%, alcançando 10.000 toneladas. Em janeiro e fevereiro deste ano, foram vendidas 1.700 toneladas, o equivalente a US\$ 2,1 milhões. O Paraguai é o maior comprador, com $28,85 \%$, o segundo é a Alemanha (23,31\%), seguidos de Itália (6,09\%), Portugal (5,68\%) e Uruguai $(5,44 \%)$.

O sabor e aroma peculiares da cachaça atraem e fascinam os estrangeiros, ainda mais por ela ser capaz de se adaptar facilmente, como base e ingrediente de coquetéis, aos bares e cozinhas de muitos países.

O padrão de identidade e qualidade da cachaça industrial e artesanal é requisito indispensável para a afirmação e crescimento do produto no exterior. Conforme verificação na pesquisa, 96\% acreditam que o produto alcançará respeito internacional. Alguns acham que será mediante um eficiente marketing por parte das indústrias e do governo. A maioria dos entrevistados (65\%) consideram que o produto tem qualidade para o mercado internacional. Um dos inquiridos ressaltou que o aspecto cultural favorece a internacionalização da cachaça.

Todos os envolvidos no processo produtivo, preocupados em manter a identidade de um produto tipicamente nacional, vêm lutando para que ele seja reconhecido no exterior, como único, genuinamente brasileiro. A mobilização dos produtores, as leis definidoras da identidade e do padrão químico da cachaça brasileira, medidas de estímulo à produção, ações de marketing e publicidade, têm sido fundamentais para o incremento das exportações do produto, transformando-o em objeto de desejo de vários consumidores em todo o mundo.

O Decreto $N^{0} 2314$, de setembro de 1997, foi a primeira norma a definir o produto, assim como definiu os parâmetros para padronização e fiscalização da bebida. Com ele foi regulamentada a lei que tratava da padronização e da fiscalização de bebidas. O Decreto № 4062, de dezembro de 2001, especificou que a utilização dos nomes cachaça e cachaça do Brasil é restrito aos produtos estabelecidos no país; e o Decreto № 4072, de março de 2002, que atualizou alguns artigos do Decreto $N^{0} 2314$, definiu caipirinha e diferenciou cachaça de rum. Com o Decreto No 4851, aprovado em 2 de outubro de 2003, a bebida passou a receber classificações de acordo com o envelhecimento e a adição de açúcar, sendo revogado expressamente o Decreto No 4072/02.

A exclusividade no nome apresenta uma vitória para o Brasil, especialmente para o setor, que poderá conquistar novos mercados e ter uma participação maior nas exportações brasileiras. 
São vários os problemas que envolvem a industrialização e a comercialização da cachaça no mercado internacional. Nos Estados Unidos, o conflito é para que a cachaça não seja identificada como rum, pois, apesar de serem feitas de cana-deaçúcar, são duas bebidas bem diferentes, de nacionalidades e características organolépticas distintas.

A cachaça tem conquistado ao longo dos anos, no Brasil e no exterior, muitos adeptos. Vem conquistando prestígio e espaço no cenário nacional e internacional, e está presente nas adegas dos melhores restaurantes. Todo bar que "se preze", deve ter a caipirinha no cardápio, diz um dos pesquisados em conversa informal.

Segundo a Federação Nacional das Associações dos Produtores de Cachaça de Alambique (Fenaca), a cachaça conhecida, na maior parte do Brasil e no exterior, é a industrial, preparada em colunas de aço de grandes destilarias, que responde por 90\% das exportações do destilado.

O setor da aguardente é composto basicamente por um grande número de empresas de micro e pequeno porte e por um grupo reduzido de médias empresas. As micro-empresas dirigem cerca de 30 mil alambiques no país, cuja produção está associada ao cultivo de outras atividades agropecuárias como, milho, feijão, café, leite e outras, e têm na produção de cachaça cerca de $50 \%$ da renda da propriedade.

De acordo com a Revista Veja (2005), o Brasil solicitará aos demais países que reconheçam a denominação cachaça. Em troca, regularizará os direitos de seus produtos aqui. A regularização tem importante implicação no reconhecimento externo da cachaça como um elemento da identidade brasileira, assim colaborando com o reforço ao valor simbólico que tem esta bebida juntamente com outros elementos de nossa cultura, como o carnaval e o futebol. 


\section{CAPÍTULO 2 \\ Raízes da Cachaça}

\subsection{Engenhos}

De acordo com Bueno (2004), Martim Afonso de Souza introduziu a cultura da cana-de-açúcar no Brasil, na capitania de São Vicente, numa expedição de 1530 a 1533, tornando-se proprietário do primeiro engenho do país, que se chamava Engenho do Governador. Sua produção era totalmente voltada para a exportação.

Já Câmara (2004) afirma que o colonizador português e mais quatro sócios construíram três engenhos em São Vicente: o Engenho dos Erasmos, conhecido como Engenho do Governador (Figura 4), o Engenho da Madre Deus e o Engenho de São João. Somente do primeiro restam ruínas, localizadas em Santos-SP.

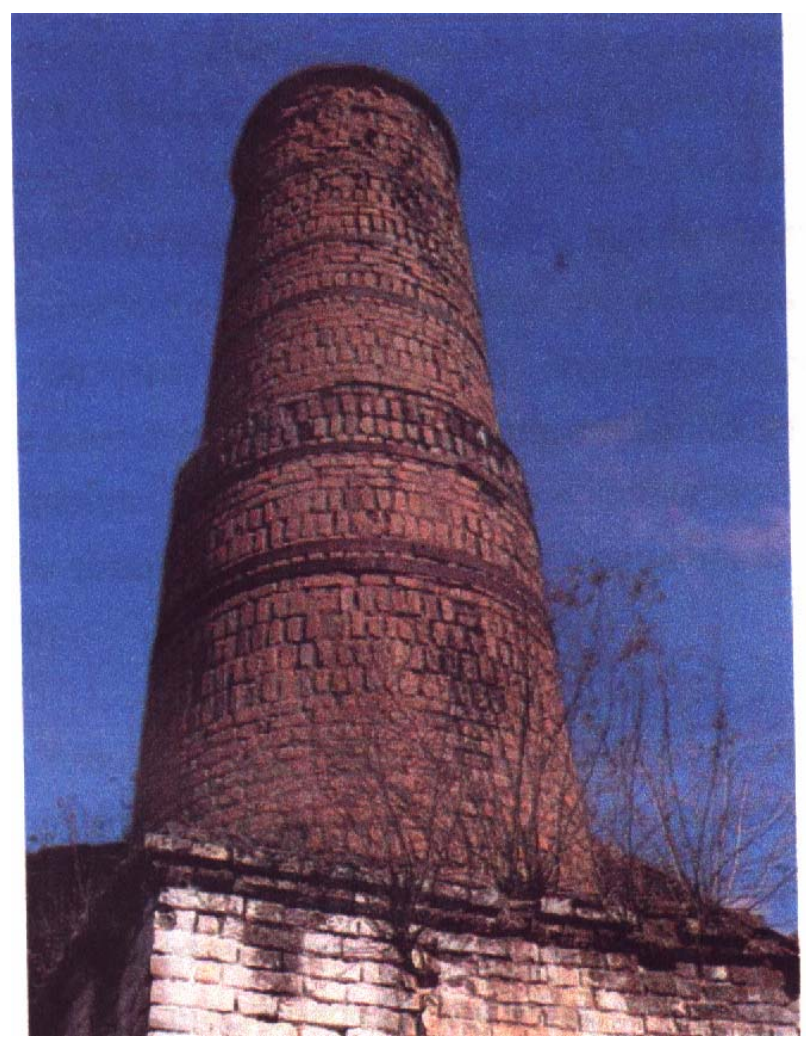

Figura 4: Ruínas do Engenho dos Erasmos (Carvalho, Murilo e Silva Silvestre, SP - 1947:11) 
A colonização da capitania de São Vicente começou com o plantio de cana e a construção de engenhos.

Lima (1999) observa que as primeiras mudas de cana, provenientes das Ilhas da Madeira e de São Tomé, foram introduzidas na capitania de Pernambuco. Seu donatário, Duarte Coelho, trouxe da Ilha da Madeira feitores especializados, agricultores com conhecimento em canaviais, que eram em grande parte judeus.

Os engenhos Salvador, de Duarte Coelho, e o Nossa Senhora da Ajuda ou Beberibe, de seu cunhado, Jerônimo de Albuquerque, foram os primeiros da capitania de Olinda.

Segundo Pires e Gomes (1994), no estado do Rio de Janeiro, o mais antigo dos engenhos, é o D’el Rei ou Pirajá, que foi construído junto à Lagoa Rodrigo de Freitas.

Mário Souto Maior (1970/71) diz que, quando Mem de Sá foi nomeado governador geral, em 1577, um de seus primeiros atos foi instalar o engenho Ceregype, no Recôncavo Baiano. Ele tornou-se o mais famoso engenho de açúcar do Brasil português.

A instalação de um engenho abrangia as plantações de cana, o equipamento para processá-la, as construções, os escravos e outros itens, como gado, pastagens, carros de transporte, além da Casa Grande e da Senzala (Figura 5).

Para Fenelon (1974) o engenho de açúcar, com seus edifícios para moradia e para instalar o aparelho necessário, formava um aglomerado humano, um núcleo de população. 


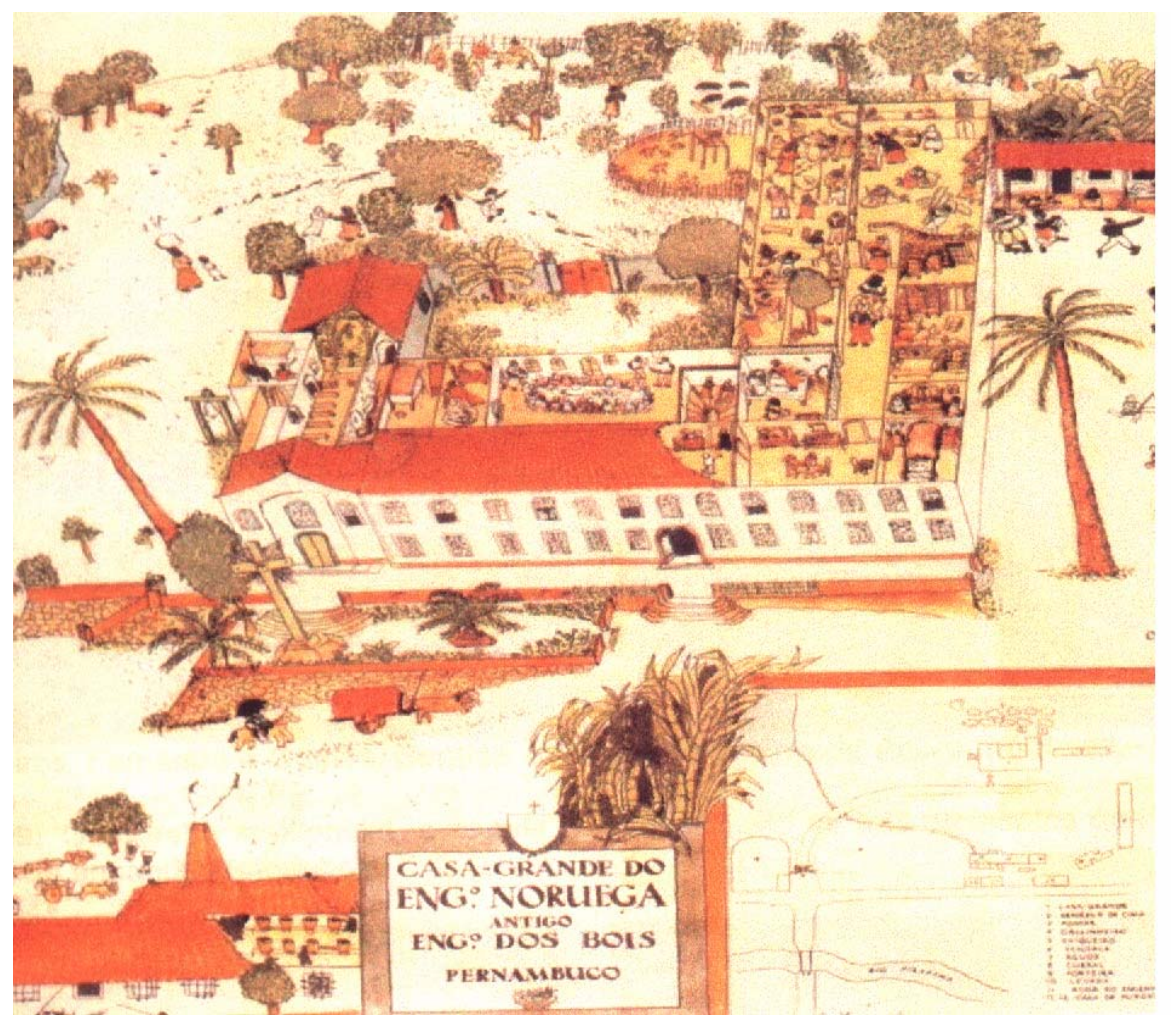

Figura 5: Planta em perspectiva da Casa Grande (Pires, Fernando; Gomes, Geraldo, RJ - 1994:41).

A Casa Grande, residência do senhor de engenho e de sua família, era uma mansão térrea ou sobrado. Tinha um estilo arquitetônico importante, que ainda hoje, empresta majestade à paisagem rural, nas velhas fazendas de açúcar que a preservaram. Era o centro de tradição de toda a atividade econômica e social da propriedade. A esse respeito vale destacar a obra de Gilberto Freyre, Casa Grande e Senzala, que apresenta uma descrição detalhada da representação da Casa Grande e da Senzala.

$\mathrm{Na}$ capela eram realizados os ofícios e as cerimônias religiosas. Próximo à ela, era construída a Senzala, habitação de escravos.

O rio e o mar foram, no período colonial, elementos fundamentais na escolha dos locais onde seria instalada a grande lavoura.

Freyre (1992) afirma que o Brasil nasceu econômica e socialmente com o açúcar. Ele foi base na formação da sociedade e na forma de família. A casa de engenho foi base de um complexo sociocultural de vida. $\mathrm{Na}$ casa da moenda, permaneciam os tambores movidos à água ou a força animal, utilizados para extrair 
o suco da cana-de-açúcar. Os engenhos d'água, de maior capacidade produtiva, eram chamados reais, por terem a realeza de moerem com água. Os outros, que moíam com cavalos e bois, são menos providos e aparelhados, eram chamados de trapiche. Registro que ainda hoje há uma usina na região sul do Estado de Pernambuco que se chama Usina Trapiche.

Rego (2002) descreve o ambiente do engenho: "O açúcar era obtido mediante a moagem da cana pela força animal ou do homem; ou por moinhos de vento ou de água, em seguida, o suco era cozido em tachos de cobre e o processo de secagem era feito em formas de terracota, chamadas de pão de açúcar". A produção do engenho era contabilizada em pães de açúcar (Figura 6).

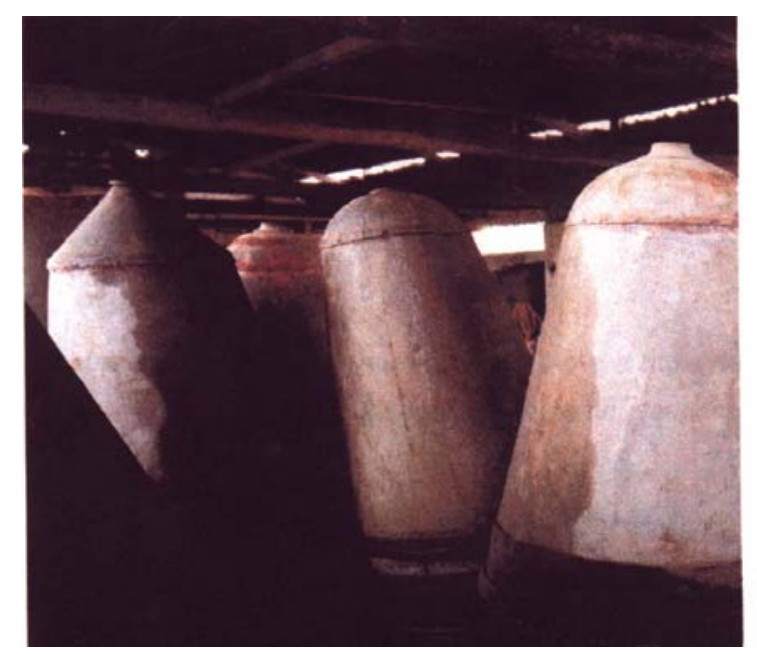

Figura 6: Pão de açúcar

(Pires, Fernando; Gomes, Geraldo, RJ - 1994:05)

Segundo Belluzo e Heck (2002), nos primeiros engenhos o processo de fabricação de açúcar era realizado nas moendas. A cana era triturada entre dois cilindros verticais de madeira, movidos por rodas d'água ou tração animal, de onde se extraía o caldo e se retirava o bagaço. Muitas vezes, era necessária uma segunda espremedura, para que se obtivesse um caldo mais grosso, e para isso, usavam pilões, nós e monjolos (Figura 7).

O caldo obtido era levado para a casa das caldeiras e fervido em grandes tachos de cobre ou ferro batido até engrossar. Era sempre mexido com enormes escumadeiras de madeira, para retirar a espuma que se formava e as impurezas. 0 
melaço era despejado em caçambas de madeira e carregado para a casa de purgar. Os escravos transferiam o melaço para as formas de barro e as encaixavam em uma grande mesa de madeira, o tendal, com buracos circulares. As formas permaneciam lá por vários dias, até a cristalização do açúcar.

Lima (1999) revela: “(...) na casa da moenda, a cana era amassada e extraída a garapa; na casa das caldeiras, o caldo era apurado e purificado; no tendal das forças, o caldo se condensava e tornava-se nublado; na casa de purgar, era branqueado, separando-se o açúcar de melhor qualidade e colocando-o em caixas de até cinqüenta arrobas, sendo então exportado para a Metrópole".

A produção de açúcar foi fator decisivo no aprendizado do trabalho com a cana-de-açúcar e seus derivados. O processo foi ficando apurado e a sensibilidade com o manejo dos utensílios foi edificando a idéia do que fazer com o caldo, que mais adiante passou a ser depositado nas dornas a fim de se obter a fermentação, propiciando os primeiros indícios de cachaça, conhecida como grapa-doida ou grapa-azeda.

O trapiche, para Cascudo (1968), era também um tipo de armazém para depósito de mercadorias.

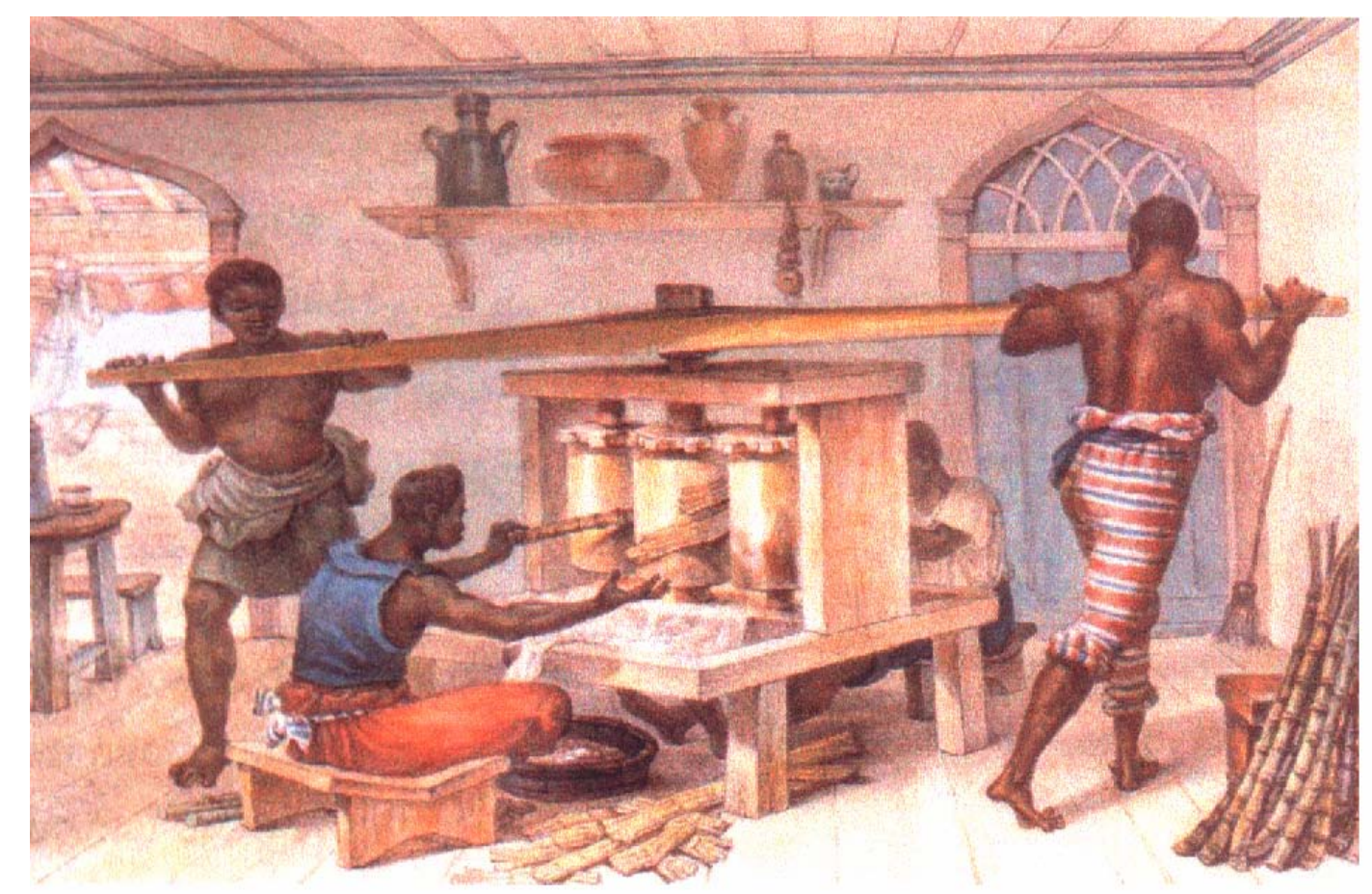

Figura 7: Pedra de mó e energia humana para extração do caldo de cana. (Bueno, Eduardo, SP - 2003:45) 


\subsection{História da cachaça}

A cultura da cana-de-açúcar no Brasil foi iniciada em 1532 e se transformou na primeira riqueza do país nos seus primeiros anos de colonização (Figura 8). Seu desenvolvimento influenciou decisivamente todos os aspectos da vida da colônia, como economia, arquitetura, distribuição geográfica da população e até mesmo sua estrutura social.

Da plantação, resultava como principal produto de exportação, o açúcar, que foi a primeira indústria. Beneficiado e comercializado pelos holandeses, e com grande aceitação no mercado europeu, o açúcar proporcionou os momentos iniciantes de prosperidade ao Brasil. Junto com essa cultura nascia um outro produto originado da cana e tipicamente brasileiro: a cachaça.

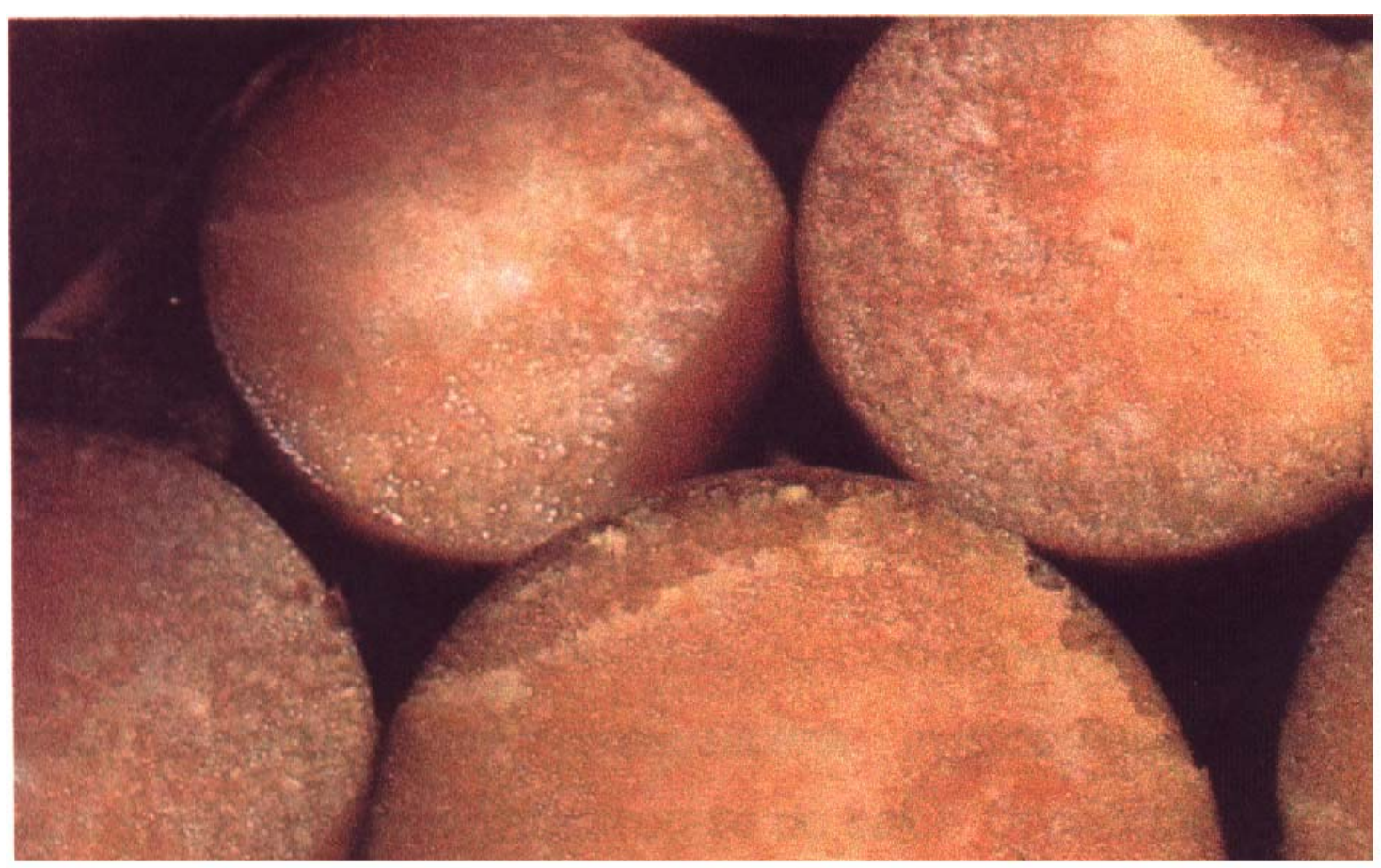

Figura 8: Corte da cana-de-açúcar (Carvalho, Murilo e Silva Silvestre,SP - 1947) 
A cachaça era uma bebida fermentada a partir da espuma que boiava nos tachos em que era fervido o suco da cana para a fabricação do açúcar. Para purificá-lo, a espuma era retirada e servida aos animais com o nome de Cagaça. Pouco tempo depois, descobriu-se que a Cagaça recolhida em potes fermentava, obtendo assim, teores alcoólicos. Da evolução da Cagaça, surgiu a denominação Cachaça.

De acordo com Câmara (2004), sua origem como bebida fermentada, está situada entre os anos de 1533 e 1534. A partir daí, surge o primeiro e típico destilado brasileiro. Tão típico e original quanto a complexa estrutura social que lhe produziu.

A cachaça acompanhou todas as mudanças ocorridas em cinco séculos de Brasil. Em 1572, a alambicagem da cana-de-açúcar já estava presente em quase todos os engenhos brasileiros. A bebida brasileira passou a fazer sucesso na Europa e na África, sendo levada pelos navegadores.

Os traficantes de escravos a utilizavam junto com o fumo e o açúcar, como moeda de troca de escravos que iriam trabalhar na lavoura colonial. Os negros aderiram rapidamente à bebida. Eles a consumiam tanto para suportar as pesadas condições de trabalho, quanto em momentos de alegria e festividades.

Em 1635, os portugueses proibiram a venda da cachaça. Essa foi somente uma das muitas outras tentativas de impedir a produção e o comércio da bebida brasileira. Já em 1654, os holandeses foram expulsos do Brasil, levando a cultura da cana para as Antilhas. Lá, foi produzida uma outra bebida, com características diferentes, destilada a partir do melaço da cana: o rum.

Durante o século XVIII, a economia baseada no cultivo da cana foi substituída pela extração do ouro em Minas Gerais.

A popularidade da cachaça aumentava proporcionalmente à impopularidade da Coroa. Alegando prejuízo à bagaceira - destilado do reino português - o rei Dom João tentou, em 1743, proibir novamente a produção da aguardente de cana. Mais um fracasso. Portugal mudou a tática de proibição e passou a taxar o produto. A título de reconstruir Lisboa, abalada por um forte terremoto em 1755, foi criado em 1756, o Imposto Voluntário. Criou também o Subsídio Literário, este destinado a manter as universidades de Portugal, principalmente as de Coimbra e Lisboa. A cachaça teve uma participação significativa nessas arrecadações. Nessa época, o 
descontentamento na colônia começou a gerar os primeiros ideais de independência que culminaram com a Conjuração Mineira e a morte de Tiradentes.

A cachaça estava presente no calor das batalhas, na dor das derrotas e na alegria das vitórias. O uso da bebida como símbolo de resistência à dominação colonial foi mantido até a proclamação da independência, em 1822, brindada com a cachaça em todo o país. Demonstração de nacionalismo e brasilidade contra as bebidas estrangeiras.

A partir de 1850, começou o declínio do trabalho escravo e intensificou-se uma nova atividade econômica no Brasil: a cafeicultura. Com ela, surgiram os Barões do Café. Nessa época, instalou-se um largo preconceito contra tudo o que era brasileiro. O preconceito manifestava-se contra os produtos nacionais, tidos como coisas sem valor, destinados a pessoas pobres e negras.

A abolição da escravatura, em 1888, contribuiu para aumentar a discriminação racial e cultural. Sem trabalho, sem teto, e sem oportunidades, os negros livres foram lançados à marginalidade social e econômica. O preconceito ganhou termos pejorativos: cachaceiro, pingunço e pé-de-cana.

Em oposição a essas idéias discriminatórias e elitistas, formou-se o movimento de intelectuais. A Semana de Arte Moderna de 1922, em São Paulo, iniciou o processo de redescobrimento de brasilidade, criticando com ironia a tentativa de importação de modelos europeus de cultura e comportamento.

Mesmo assim, a cachaça continuou vítima do preconceito e da ignorância. Atualmente, ela pode ser comparada aos melhores destilados do mundo e ainda assim, é vista como de má qualidade e dirigido a paladares pouco refinados.

Um passo muito importante foi dado nas festividades dos 500 anos de descobrimento do Brasil. A cachaça foi servida para a delegação portuguesa no brinde oficial da comemoração como símbolo de brasilidade e relação amistosa com outros povos.

Criado em 1997, no interior da Associação Brasileira de Bebidas (ABRABE), o Programa Brasileiro de Desenvolvimento da Cachaça (PBDAC) mantém ações que vão desde discussões, cursos e propostas técnicas para aprimorar a qualidade do produto, até a divulgação institucional da bebida no exterior, visando ocupar o enorme potencial exportador da bebida. 
Por sua forte identificação com a história e a cultura brasileira, seu consumo não pode ser desvinculado de tudo o que se refere ao Brasil, da mesma forma que o futebol, o carnaval e a música brasileira. 


\section{CAPÍTULO 3}

\section{Cachaça e cultura}

\subsection{A cachaça e a Cultura Brasileira}

A cachaça sustentou a escravaria, o braço trabalhador nos ciclos da cana-deaçúcar, do ouro e do café (Figura 9). Foi, essencialmente, a bebida dos negros, dos primeiros brasileiros, mestiços, caboclos e índios. Os senhores de engenho e as autoridades sempre lucraram muito com ela, mas a tomavam envergonhadamente.

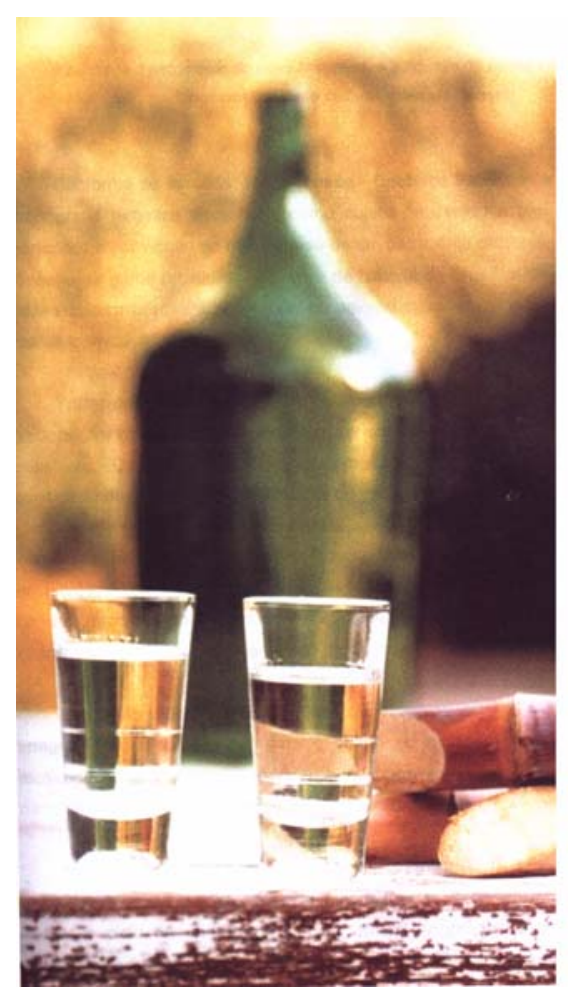

Figura 9: Cachaça.

(Doces sabores, SP - 2002:39)

O preço barato da bebida e o seu consumo democrático fizeram da história da cachaça uma história muito parecida com a do povo brasileiro, mercadorias 
subalternizadas, reprimidas e exploradas pelas elites. Todas as lutas, derrotas e conquistas sociais, políticas, econômicas e culturais do povo brasileiro foram, pelo menos, umedecidas pela cachaça, como a Revolução de Minas, que martirizou Tiradentes em 1789, a Revolução Pernambucana de 1817, e outras.

Ela sempre esteve presente no calor das batalhas, na dor das derrotas, na alegria das vitórias; foi, em vários momentos da história brasileira, a marca da Independência e da soberania da Nação. Foi festejada nos anos 50 até ser julgada imoral e subversiva, estigmatizando seus bebedores, na ditadura militar que infelicitou o País, de 1964 a 1985.

A cachaça integra a identidade do povo brasileiro. Como ressalta Martins (2003:43), identidade nada mais é que a conseqüência de pertencer a um grupo ou comunidade culturalmente homogênea e socialmente definida. Ela está na memória da nação e, por isso, não é propriedade particularizada de nenhum grupo social, mas sim, universal, que se impõe a todos os grupos. Para Ortiz (1994:138) "A memória nacional opera uma transformação simbólica da realidade social, logo, não pode coincidir com a memória particular dos grupos populares".

A cachaça faz parte do patrimônio material e imaterial do povo brasileiro. De acordo com o Centro Cultural UFMG, Patrimônio Material é a representação física, móvel ou imóvel de expressões culturais. Para o IPHAN, o Patrimônio Cultural Imaterial, são as práticas, representações, conhecimentos e técnicas que as comunidades, os grupos e, em alguns casos, os indivíduos reconhecem como parte integrante do seu patrimônio cultural. Ela está presente em inúmeras manifestações da cultura brasileira, especialmente no universo popular e folclórico. Está integrada nas artes, na religiosidade, principalmente num segmento do espiritismo, nas festas, na culinária, medicina, música, enfim, no cotidiano das pessoas, de lazer, prazer, sonho, trabalho e realização.

Por ser considerada a bebida do povo brasileiro, representa muito mais que um produto econômico, uma mercadoria; é uma das mais significativas expressões da cultura brasileira.

Através de sua carga simbólica, e de como ela se manifesta, o povo se entende, se comunica, celebra, festeja, faz oferendas, clama, canta a vida e chora os desencantos e os seus mortos. Uma prova de sua vitalidade cultural está nas centenas de nomes pelos quais o povo a chama (Quadro 1). 
Quadro 1: Terminologias usadas para cachaça (Câmara, 2004)

\begin{tabular}{|c|c|c|c|}
\hline A & B & C & D \\
\hline $\begin{array}{l}\text { Abençoada } \\
\text { A boa } \\
\text { Abrideira } \\
\text { Água-benta } \\
\text { Água-p'ra-tudo } \\
\text { Aguardente } \\
\text { Azuladinha }\end{array}$ & $\begin{array}{l}\text { Bagaceira } \\
\text { Birinaite } \\
\text { Boa-p'ra-tudo } \\
\text { Boinha } \\
\text { Branquinha } \\
\text { Brasileirinha } \\
\text { Brava }\end{array}$ & $\begin{array}{l}\text { Cachaça } \\
\text { Cana } \\
\text { Caninha } \\
\text { Caxixi } \\
\text { Chora-menina } \\
\text { Consola-corno } \\
\text { Cura tudo }\end{array}$ & $\begin{array}{l}\text { Danada } \\
\text { Dengosa } \\
\text { Desgraça } \\
\text { Desmanchada } \\
\text { Dindinha } \\
\text { Doidinha } \\
\text { Dona branca }\end{array}$ \\
\hline$E$ & $\mathbf{F}$ & G & $\mathbf{H}$ \\
\hline $\begin{array}{l}\text { Ela } \\
\text { Elixir } \\
\text { Espanta-moleque } \\
\text { Esquenta-corpo } \\
\text { Esquenta-dentro } \\
\text { Estricnina } \\
\text { Extrato-hepático }\end{array}$ & $\begin{array}{l}\text { Faísca } \\
\text { Fecha-corpo } \\
\text { Ferro } \\
\text { Filha-do-engenho } \\
\text { Fogo } \\
\text { Fogosa } \\
\text { Forra-peito }\end{array}$ & $\begin{array}{l}\text { Garapa } \\
\text { Garapa-doida } \\
\text { Gás } \\
\text { Girgolina } \\
\text { Gole } \\
\text { Goró } \\
\text { Gororoba }\end{array}$ & Homeopatia \\
\hline I & J & $\mathbf{L}$ & M \\
\hline $\begin{array}{l}\text { Igarapé-mirim } \\
\text { Imaculada } \\
\text { Imbiriba } \\
\text { Injeção } \\
\text { Insquento } \\
\text { Isbelique } \\
\text { Isca }\end{array}$ & $\begin{array}{l}\text { Januária } \\
\text { Jeribá } \\
\text { Jeribita } \\
\text { Jinjibirra } \\
\text { Juçara } \\
\text { Junca } \\
\text { Jurubita }\end{array}$ & $\begin{array}{l}\text { Lapada } \\
\text { Lapinga } \\
\text { Lebréia } \\
\text { Limpa-goela } \\
\text { Limpinha } \\
\text { Lisinha } \\
\text { Luanda }\end{array}$ & $\begin{array}{l}\text { Maçangana } \\
\text { Malafa } \\
\text { Malvada } \\
\text { Malunga } \\
\text { Mamadeira } \\
\text { Mata-paixão } \\
\text { Mulata }\end{array}$ \\
\hline $\mathbf{N}$ & 0 & $\mathbf{P}$ & $\mathbf{Q}$ \\
\hline $\begin{array}{l}\text { Não-sei-quê } \\
\text { Negrita } \\
\text { Nó-cego } \\
\text { Nordígena } \\
\text { Número um }\end{array}$ & $\begin{array}{l}\text { Óleo-de-cana } \\
\text { Oranganje } \\
\text { Ori } \\
\text { Otim }\end{array}$ & $\begin{array}{l}\text { Paixão } \\
\text { Paraty } \\
\text { Patrícia } \\
\text { Passa-raiva } \\
\text { Péla-goela } \\
\text { Perigosa } \\
\text { Pinga }\end{array}$ & $\begin{array}{l}\text { Quebra-gelo } \\
\text { Quebra-jejum } \\
\text { Quindim }\end{array}$ \\
\hline $\mathbf{R}$ & $\mathbf{S}$ & $\mathrm{T}$ & $\mathbf{U}$ \\
\hline $\begin{array}{l}\text { Remédio } \\
\text { Restilo } \\
\text { Retroz } \\
\text { Rija } \\
\text { Ripa } \\
\text { Roxo-forte }\end{array}$ & $\begin{array}{l}\text { Saideira } \\
\text { Santinha } \\
\text { Supupara } \\
\text { Sem nata } \\
\text { Sete virtudes } \\
\text { Sinhazinha } \\
\text { Sumo da cana }\end{array}$ & $\begin{array}{l}\text { Teimosa } \\
\text { Tempero } \\
\text { Terebintina } \\
\text { Tira-calor } \\
\text { Tira-juízo } \\
\text { Tira-teima } \\
\text { Tome-juízo }\end{array}$ & $\begin{array}{l}\text { Uca } \\
\text { Uma } \\
\text { Unganjo } \\
\text { Upa } \\
\text { Usga }\end{array}$ \\
\hline V & $x$ & Z & \\
\hline $\begin{array}{l}\text { Vela } \\
\text { Veneno } \\
\text { Venenosa } \\
\text { Virgem }\end{array}$ & $\begin{array}{l}\text { Ximbica } \\
\text { Ximbira } \\
\text { Xinabre } \\
\text { Xinapre }\end{array}$ & Zuninga & \\
\hline
\end{tabular}


É verdade que ricos e classe média bebem cachaça com raiva, como se fosse um remédio ruim. O sentimento é o de que estão transgredindo uma regra da sua classe, estão realizando uma ousada permissividade social. Eles, que sempre desprezaram, menosprezaram a cachaça como produto econômico, não a reconhecem como uma expressão da Cultura Brasileira. No máximo, a vêem como um produto exótico, uma extravagância popular. Bebem cachaça como se estivessem fazendo uma concessão social, ofertando uma benesse política ao pobre e sacrificado povo.

Sabe-se que na maioria das vezes, a elite bebe destilados estrangeiros e não a cachaça brasileira, como símbolo de status social e econômico. As pessoas não querem ser reconhecidas como bebedoras de cachaça, alcoólatras, vagabundas ou marginais.

A preservação e a valorização da cultura espontânea garantem a sobrevivência da autenticidade da cultura brasileira. A tradição popular acerca da cachaça desdobra-se em diversas manifestações e ritos: as crendices, as advinhas e as serenatas. É um conjunto de práticas do cotidiano e contemplado no imaginário dos brasileiros.

A serenata é um gênero musical que gozou de extrema popularidade no Brasil durante muito tempo. É definida por Mário Souto Maior (1970/71) como canto ou música instrumental executados ao sereno, ao ar livre, diante da casa da pessoa a quem se dedica a homenagem.

Sobre cachaça e serenata, Mário Souto Maior (1970/71), na poesia que se segue, descreve a relação serenata, lua e cachaça, trio indissolúvel no cancioneiro popular.

\footnotetext{
Oh! Cachaça amiga

Não há quem me diga

Que não tens valor.

Por seres tão boa

Vives assim, à toa

Sem saber se impor
}

Ela dá coragem

Ela dá vantagem 
Dá inspiração

E não admite

Falta de apetite

Numa refeição

A moça solteira

Que por brincadeira

Toma seu pifão.

Quem não gosta dela

Debaixo da cama

Tem um garrafão

Essa gente boa

Que também gostando

Desta brincadeira

Desde a cozinha

Até a patroa

Também na medicina popular, o uso da cachaça se expandiu pelo Brasil, em decorrência principalmente do difícil acesso da população aos serviços médicos oficiais. A relação entre o número de pacientes e os médicos disponíveis, ainda é hoje, desigual. Isso fez com que houvesse uma procura pela medicina popular, de transmissão oral. Nessa medicina praticada e transmitida pelo povo, a cachaça é bastante utilizada como veículo para as macerações e infusões de raízes e ervas, como base para as famosas garrafadas. Para cada mal ou doença, encontra-se nas feiras e mercados populares e nas práticas dos curandeiros, uma garrafada específica: para curar gripe, reumatismo, impotência, etc. 


\subsection{Futebol e cachaça}

Bebida popular, vulgarizada, perseguida e subalternizada pelas elites, a cachaça é enredo, personagem, elemento de inúmeras manifestações do folclore brasileiro, tanto quanto patrimônio material e imaterial.

Sempre presente no imaginário popular é um elemento, assim como o futebol e o carnaval, da identidade nacional do brasileiro. Dos entrevistados nesta pesquisa, 87\% têm a idéia de que os principais consumidores pertencem à classe baixa.

O futebol, paixão nacional, é uma catarse coletiva deflagradora de múltiplas manifestações populares, em que a cachaça é o brinde nas vitórias e o consolo nas derrotas. Futebol, carnaval e cachaça recortam o cotidiano do brasileiro, da pluralidade das manifestações.

Da Matta (1986:22), afirma que o futebol mostra um lado que fala do estilo brasileiro de ser, do modo como se classificam as coisas, da maneira pela qual se gosta de viver e deixar de viver.

O futebol foi introduzido no Brasil há mais de cem anos, por uma elite, até se tornar o esporte mais popular. Neste estudo, constata-se que 61\% concordam que há associação da cachaça com o futebol. Para eles, o futebol é uma forma de alavancar as vendas mediante as grandes comemorações do evento, seja na vitória ou na derrota.

Além disso, para os informantes, o futebol brasileiro, por ser reconhecido mundialmente, pode vir a ser um meio de propagação da bebida de mesma nacionalidade, no cenário externo.

\subsection{Cachaça e comida}

As relações entre a cachaça e a comida despertam comentários e manifestações populares mais variadas. Suas articulações estabelecem vínculos e 
processos de comunicação que remetem aos hábitos alimentares dos escravos brasileiros.

Assim como a comida, a bebida é percebida e valorizada enquanto uma manifestação de sensibilidade e de comunicação entre as pessoas. Ela exige todos os sentidos e sentimentos para ser então, verdadeiramente, integrada ao corpo e ao espírito. É justamente na boca, que a bebida é integralmente entendida, ganhando valor simbólico. Segundo Lody, "Comer não é apenas um ato complexo biológico. É antes de tudo um ato tradutor de sinais, de reconhecimentos formais, de cores, de texturas, de temperaturas e de estéticas" (2005:30).

Da mesma forma, beber é um ato que une memória, desejo, significados, sociabilidades, ritualidades que diz da pessoa que ingere a bebida, do contexto em que vive, comunicando também com os demais que participam do momento do ato de beber; identificando assim, extratos sociais.

Alia-se a esse pensamento, Le Goff (1990:476) que considera a memória como um elemento essencial do que se costuma chamar identidade, individual ou coletiva, cuja busca é uma das atividades fundamentais dos indivíduos e das sociedades atuais, na febre e na angústia.

A memória coletiva só pode existir enquanto prática que se manifesta no cotidiano das pessoas. Lima (1999) observa que os escravos mastigavam alho e recebiam cachaça pela manhã, e ao se recolherem, para fechar o corpo contra as doenças.

Alimentos e bebidas são elementos de relevância na conformação psicológica dos indivíduos e suas relações estão presentes na memória e no cotidiano de todas as culturas, com diferentes matizes e em diferentes gradações.

$\mathrm{Na}$ cultura brasileira, diversas situações cotidianas explicitam claramente esta complexa dimensão do ato de se alimentar. A função da cachaça, tomada antes das refeições, é uma delas: ao ser bebida, tem ao mesmo tempo uma função higiênica, pois limpa a boca e a garganta; e uma função gustativa, que prepara as papilas para uma perfeita degustação da refeição que será apreciada.

O valor cultural do ato de beber é cada vez mais entendido enquanto um ato patrimonial, pois a bebida é tradutora de povos, nações, civilizações, grupos étnicos, comunidades, famílias, pessoas.

A bebida é um lugar que define e aufere a pessoa ao seu pertencimento, a ter uma identidade, definindo papéis sociais de homens e mulheres. A boca do 
brasileiro, desde as suas primeiras relações com a Europa e a África, é enriquecida com sabores de diferentes partes do mundo. O gosto é mundializado a partir do século XVI com a chegada colonial fortemente plantada na cana-de-açúcar.

De acordo com o costume nordestino, uma dose de cachaça adoçada é presença garantida nos domingos ensolarados, nas festas de batizados, nos casamentos, ou quando se comem pratos regionais de resistência (buchada, rabada).

Quando misturada a frutas, é uma verdadeira sinfonia de cores e sabores. As combinações são inúmeras. O gelo e o açúcar estão praticamente em todas as receitas, mas o segredo está na maneira ou na intensidade de bater, mexer ou apenas misturar os alimentos.

A combinação mais pedida é a da cachaça com limão, açúcar e gelo: a popular caipirinha. Essa mistura casual transformou-se em uma das maiores preferências nacionais e internacionais.

Algumas receitas pedem a cachaça. Segundo a crença popular, a carne de porco, se lavada com aguardente, ficaria livre da raiva que o animal sente na hora do abate, e de seu cheiro forte. Assim como a massa de pastel, para que ela fique mais leve e crocante, é recomendável adicionar uma dose de cachaça durante a mistura de seus ingredientes. A feijoada tem em geral, como abrideira, uma batida ou um gole de cachaça (Figura 10).

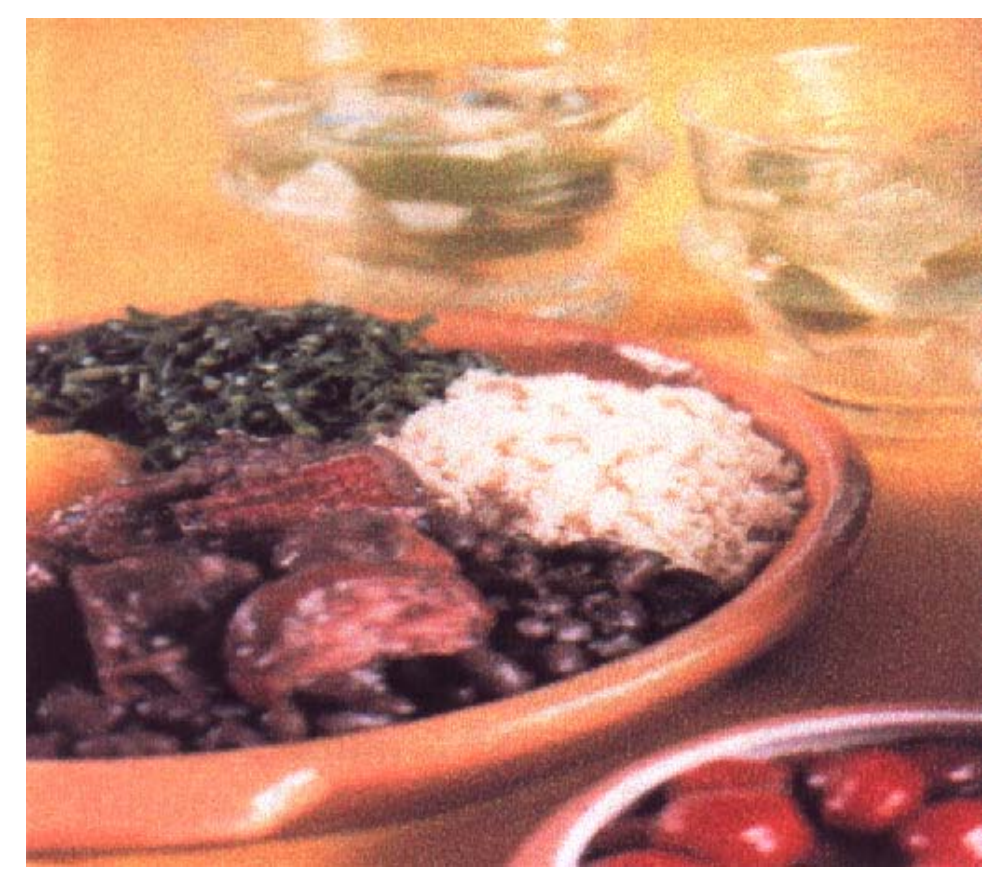

Figura 10: Feijoada e caipirinha (Caipirinha, RJ - 2003:78) 
As escolhas e formas de integrar a bebida à vida fazem com que o brasileiro se sinta mais brasileiro, fortalecendo o lugar de pertencimento, de fazer parte de uma cultura, de um povo, de uma nação.

A cachaça é apreciada também na sobremesa com doces de calda, compotas, nos recheios de chocolate, bombons, gelatinas, bolos, mousses e tortas. Tudo pode ser preparado com um pouquinho de cachaça.

Para Freyre (2003) as batidas brasileiras são uma expressão da hospitalidade nacional, da mesma forma que o cafezinho.

O açúcar faz as identidades do brasileiro nas cozinhas, nas feiras, nos mercados. À mesa, celebram as relações sociais onde são fortalecidos os elos de pertencimento, de ter uma cultura, enfim, de pertencer a uma família, uma sociedade, um povo, um país.

\subsection{Rótulos}

Os fabricantes de cachaça descobriram nos rótulos das garrafas uma poderosa estratégia de marketing e passaram a relacioná-los aos fatos sociais, políticos, econômicos e culturais do país.

Os rótulos das cachaças brasileiras são instrumentos de manifestação dos sentimentos que consagram o consumo da cachaça. São o espaço discursivo para o humor e para a crítica. Afina a ironia, dialoga com a literatura de cordel, com a música, exprime dimensões da religiosidade popular, da crítica política e social.

Algumas cachaças podem até não ser de boa qualidade, mas seus rótulos têm a função de encantar, atrair, emocionar, ou até mesmo provocar uma gargalhada. À medida que se foram integrando ao cotidiano dos brasileiros, os rótulos passaram a refletir também sentimentos, desejos, dúvidas e a fé religiosa.

De acordo com o folclorista Danilo Fragoso, os rótulos podem espalhar inclusive estados de espírito ocasionais dos fabricantes e engarrafadores de cachaça, e refletem, sobretudo, o comportamento espiritual de uma classe. 
Quando no governo do presidente Juscelino Kubitscheck de Oliveira, a capital do país foi transferida para o Planalto Central, e apareceu a cachaça Brasília; denominação que remete a cachaça a momentos políticos da história nacional.

Com a vitória do Brasil na Copa do Mundo de 1970, Pelé consagrou-se rei do futebol. Como parece óbvio, sua imagem resultou na caninha Pelé. Por motivos lógicos, o Atleta do Século não gostou da "homenagem" e chegou, inclusive, a processar o fabricante, que foi obrigado a retirar o produto do mercado. Mas muitos já haviam conseguido um exemplar da bebida, guardada com muita paixão. Afinal, cachaça e futebol são duas grandes paixões do povo brasileiro.

Mostrando a alma poética do povo brasileiro, aparecem os rótulos com os dizeres "Sem Vergonha", "Ressaca", "Coragem" e "Serenata".

O espaço do rótulo é também veículo para a manifestação da insatisfação política do povo. Por meio do humor, ironizam-se as promessas políticas e faz-se alusão à partidos políticos e a personagens desse universo: Cachaça do Senador e PMDB, a cachaça do povo, que apareceu nas eleições de 1982.

Podem ainda trazer hábitos cotidianos e nomes que indicam ritmos ou canções conhecidas da música brasileira: Forró, Samba e Bossa-Nova.

No âmbito da religiosidade popular, as estampas dos rótulos podem traduzir crenças e rituais, ou ainda reverenciar elementos sagrados, entidades e santos, como as cachaças Pai de Santo, Santa Maria e São Francisco.

Muitos rótulos referenciam a mulher brasileira, ora homenageando-a com adjetivos carinhosos, ora colocando-a como objeto de desejo, como: Saborosa, Jeitosa, Sedutora e Gostosa. Segundo a crendice popular, as mulheres apenas poderiam ingerir cachaça durante o resguardo ou para alívio de cólicas menstruais, adicionando à ela ervas medicinais. Atualmente, o consumo de cachaça entre as mulheres está aumentando. Na pesquisa realizada, observou-se que 50\% (7) das mulheres aprecia cachaça e seus derivados. Ressalta-se que 57\% delas são casadas.

O investimento em embalagens diferenciadas, com rótulos bem concebidos, tem contribuído para agregar valor ao produto e melhorar a imagem da bebida. Algumas embalagens expressam sentimentos de brasilidade; outras, rusticidade. $\mathrm{O}$ objetivo é atingir públicos mais exigentes no mercado de bebidas. 
A garrafa pode ser de vidro, porcelana ou cerâmica, revestida de palha ou corda. As tampas são outro elemento importante nas embalagens. Podem ser de plástico injetado, com bico dosador, ou somente rosqueado de alumínio.

Os três elementos da embalagem da cachaça formam um conjunto fundamental para o destaque do produto no mercado, porém, não se pode desconsiderar que o equilíbrio entre tradição, popularidade, brasilidade e sofisticação é o que de fato garante a permanência da aguardente na preferência nacional.

A Associação Mineira dos Produtores de Cachaça de Qualidade (AMPAQ) é uma Associação respeitada no território nacional, não só por sua seriedade em tratar da produção da cachaça, mas também por possuir em seu quadro social as maiores e as mais famosas cachaças do mercado. Além do mais é a única Associação a lançar com absoluto sucesso o SELO DE GARANTIA DE QUALIDADE AMPAQ. 


\section{CAPÍTULO 4}

\section{Folclore}

\subsection{Origem e conceito}

A palavra folclore é de origem inglesa, folk (povo) e lore (saber) e significa sabedoria popular. Foi usada pela primeira vez em 1846, pelo arqueólogo inglês William Jonh Thoms, para substituir a expressão "antigüidades populares". Depois de certo tempo, o termo passou a ser universalmente aceito. Entende-se que Folclore são as manifestações artísticas e culturais de um povo. É o conjunto de costumes, crenças, tradições, lendas, provérbios, danças, e canções, transmitidos a cada geração.

Segundo Araújo (1997), em 17 de Agosto de 1965, pelo Decreto № 56.747, foi criado o dia do Folclore no Brasil, nos seguintes termos:

"O Presidente da República, usando a atribuição que Ihe confere o art. 87, inciso I, da Constituição Federal e;

Considerando a importância crescente dos estudos e as pesquisas do folclore em seus aspectos antropológico, social e artístico, inclusive como fator legítimo, para maior conhecimento e mais ampla divulgação da cultura popular brasileira:

Considerando que a data 22 de Agosto, recordando o lançamento pela primeira vez em 1846 da palavra "folk-lore", é consagrada a celebrar este evento;

Considerando que o governo deseja assegurar a mais ampla proteção às manifestações da criação popular, não só estimulando a sua investigação e estudo, como ainda defendendo a sobrevivência dos seus folguedos e artes como elo valioso da continuidade tradicional brasileira, decreta:

Art. $1^{\circ}$ - Será celebrado, anualmente, a 22 de Agosto, em território nacional, o Dia do Folclore.

Art. $2^{\circ}$ - A campanha de defesa do Folclore Brasileiro do Ministério da Educação e Cultura e a Comissão Nacional de Folclore, do Instituto Brasileiro de Educação, 
Ciência e Cultura e respectivas entidades estaduais, deverão comemorar o Dia do Folclore e associarem-se a promoções de iniciativa oficial ou privada, estimulando ainda nos estabelecimentos de curso primário, médio e superior, as celebrações que realcem a importância do Folclore na formação cultural do país."

O adagiário da cachaça é muito rico e é expresso de forma sucinta. Como os alimentos e as bebidas sempre estiveram presentes nos eventos festivos, é natural que se considere a cachaça como elemento fundamental a estas manifestações populares.

"Mulher, cachaça e bolacha, em toda parte se acha"

"Não há mulher sem graça, nem festa sem cachaça"

"Mulher, briga e cachaça, estão sempre na praça".

O repentista José da Costa Leite (1970), registrou os dez mandamentos do cachaceiro, sem a intenção de falar mal das coisas de Deus:

Agora, os dez mandamentos

Vou the ensinar também

Primeiro, não beber pouco

Sozinho ou com alguém

Segundo, entrar no pajeio

Só aceitar copo cheio

E não dar pra ninguém.

Terceiro, quando acordar

Ver a bebida primeiro

Quarto, tomar um pileque

E dar também à companheira

Beber alegre e contente

Em duas horas somente

O dia e a noite inteira.

Quinto, ter todo cuidado

E não beber cana ruim

Sexto, só viver sentado 
No bar ou no botequim

Sétimo, só beber fiado

E depois ficar zangado

O sabido faz assim.

Oitavo, fazer regime

E só beber cana fria

Andar com uma garrafa

Para ter mais garantia

E quando estiver ruim

Cair onde tem capim

Porque a cana é macia.

Nono, quando melhorar

Beber de novo com sobra

Até encher a barriga

E o copo fazer manobra

Bebendo pouco é pior

Pois a pancada maior

É sempre a que mata a cobra.

Décimo, só beber no bar

Chorar na rampa ou pita

E fazer um tira gosto

Com a perna dum peru

Ou a pata dum caranguejo

Tem gente que faz com queijo

Eu gosto mais de caju.

São estes os mandamentos

Do cachaceiro sabido

Os 10 se encerram em 2

Eu já estava esquecido

Mas digo sem arroteio

É um copo grande, cheio

E um caranguejo cozido. 
A cachaça aparece freqüentemente em canções e poemas de autores brasileiros como lenitivo para as dores de amor. Um bom exemplo é o clássico 0 Ébrio, de Vicente Celestino, um dos mais famosos compositores e intérpretes de canções que falam de amores não correspondidos:

\author{
Tornei-me um ébrio \\ e na bebida busco esquecer \\ aquela ingrata que me amava \\ e que me abandonou \\ apedrejado pelas ruas \\ vivo a sofrer \\ não tenho amigos e nem parentes \\ tudo terminou..
}

Nelson Werneck Sodré apud Ortiz (1994) afirma que só é nacional o que é popular. A memória nacional é o prolongamento da memória coletiva popular, que por sua vez é particularizada, enquanto a memória nacional é universal.

A cultura popular é heterogênea, as diferentes manifestações folclóricas não partilham um mesmo traço em comum. Ela é plural. O folclore brasileiro é muito rico e revela a influência dos povos que contribuíram para a formação da nação. Como universo simbólico de conhecimento, se aproxima do mito e se revela como o saber do particular. Ele está presente na identidade do brasileiro, é revelador de cada um, de suas origens e filiações e têm uma característica importante, que é a oralidade.

A literatura oral é alimentada, transformada em memória de seus portadores. Cada contador de estórias acrescenta algo à versão antiga de narrativa.

Sabe-se que a literatura oral encerra a sabedoria popular, devido ao conjunto de provérbios, sentenças e adágios. Eles têm uma força indiscutível, constituem-se por vezes, numa argumentação que não permite discussão, como:

\footnotetext{
"Casa de ferreiro, espeto de pau"

"Quem ama o feio, bonito lhe parece"

"Quem brinca com fogo, acaba se queimando"
} 
O candomblé tende a manter uma tradição fixada nos tempos passados. Esta dimensão de preservação da tradição se manifesta na sua estrutura de culto assim como na ênfase que se dá à transmissão oral do conhecimento.

Para Araújo, "O folclore é essencialmente dinâmico, se encontra em constante transformação, através do encontro de folclores diferentes, que, em contatos contínuos originam mudanças e o aparecimento de novos elementos em cada um deles" (1997:30).

De fato, observa-se que com o passar do tempo, esse intercâmbio entre folclores diferentes provoca o surgimento de fatos novos.

A cachaça faz parte das raízes e da cultura do Brasil, mas foi marginalizada, assim como a música. Tem sido fonte de inspiração para diversas composições musicais, que se eternizaram nos bailes e enredos carnavalescos. Em 1953, os autores Mirabeau Pinheiro L. de Castro e H. Lobato compuseram uma marchinha que animou o carnaval:

Se você pensa que cachaça é água.

Cachaça não é água, não.

Cachaça vem do alambique

e água vem do ribeirão.

Pode me faltar tudo na vida:

Arroz, feijão e pão.

Pode me faltar manteiga

E tudo mais...não faz falta, não.

Pode me faltar o amor,

Isso eu até acho graça.

Só não quero que me falte

A danada da cachaça! 


\subsection{Festas populares brasileiras}

Costuma-se dizer que brasileiro é festeiro. Algumas manifestações folclóricas são de caráter nacional e outras, de caráter regional. As de caráter nacional são o carnaval e as festas juninas.

Manifestação que confere uma capacidade reveladora dos conflitos permeadores das sociedades, o carnaval é um ritual no qual está inserida uma lógica simbólica e cultural. Os brasileiros vêem no Brasil, o país do carnaval.

Com o nome de entrudo (princípio da Quaresma), o carnaval chegou ao Brasil no século XVII, trazido pelos portugueses como forma alegre, mas agressiva de brincar. As pessoas jogavam água umas nas outras, com misturas de farinha de trigo e às vezes cal. A água foi substituída pelas serpentinas e pelos confetes, e durante um tempo, pelo lança-perfume, proibido desde o século XX.

Nos primeiros anos da República, surgiram as sociedades carnavalescas, blocos e outros grupos de foliões que saiam às ruas para dançar e cantar músicas anônimas.

A pianista, maestrina e precursora da luta pelos direitos da mulher, Chiquinha Gonzaga, com a marcha Ô abre alas (1899), inaugura a prática das composições feitas exclusivamente para o grupo dos foliões, hoje uma das principais características dos desfiles das escolas de samba.

O carnaval é a maior manifestação de cultura popular do país, ao lado do futebol. Sua duração aumenta com o passar dos anos. Inicialmente, era uma festa que ia de Domingo a Terça-Feira, anteriores à Quaresma. Com o tempo, o início da festa recuou um dia para o sábado, depois mais outro para a sexta. Nos últimos anos, há bailes em toda a semana pré-carnavalesca.

A cachaça é amplamente consumida durante o carnaval, por estar mais ao alcance do poder aquisitivo dos menos abastados, por seu efeito rápido, sua popularidade e facilidade de consumo

O símbolo coletivo do espetáculo disfarça as desigualdades sociais, porém, logo as denuncia através de um mapeamento traçado no espaço social. Dificilmente, encontram-se representantes da elite no carnaval de rua a não ser em locais reservados, como camarotes, onde é garantida a não mistura com a classe popular. 
No carnaval, o corpo em movimento orienta-se em direção à liberdade e à exaltação. Potencializam-se os processos de significação, como ambigüidade, igualdade e conflito.

De acordo com Rosa (2002), o carnaval não acaba com as hierarquias nem com as desigualdades, mas sua irreverência abre uma relação mais livre, menos fatalista, com as convenções herdadas, possibilitando novas concepções corporais.

Da Matta, discorre sobre o desgaste do corpo a favor do prazer: "No carnaval, trocamos o trabalho que castiga o corpo (...) pelo uso do corpo como instrumento de beleza e de prazer. No trabalho, estragamos, submetemos e gastamos o corpo. No carnaval, isso também ocorre, mas de modo diverso. Aqui o corpo é gasto pelo prazer" (1986).

No carnaval, patrimônio não é só a arquitetura tombada, preservada, usada como ponte móvel para se sentir em outro tempo e espaço, mas a ela são somados os valores atribuídos à memória da festa.

Outras manifestações folclóricas, de caráter nacional, são as festas juninas que acontecem no mês de Junho em todo o Brasil, com comidas típicas, fogos e danças de quadrilha nos dias consagrados a Santo Antônio (13), São João (24) e São Pedro (29). A cachaça está sempre presente nos festejos juninos e nas romarias, bem como nas diversas festas populares do Brasil. No levantamento, $78 \%$ afirma que a cachaça é consumida em festas populares, e 100\% a tem como um importante elemento da cultura nacional, por ser um produto tipicamente brasileiro, advindo do período Brasil-colônia.

As maiores comemorações acontecem no Nordeste, onde o dia de São João costuma ser feriado. Mário Souto Maior (1970/71) descreve algumas receitas comuns em festas juninas:

- Rosa-sol: cachaça, erva-doce, canela em pau, cravo e calda grossa de açúcar;

- Canelinha: cachaça, canela em pó, gengibre e cacau, bem fervida;

- Cachimbo: cachaça, mel e gotas de limão;

- Quentão: cachaça, gengibre, cravo, canela, erva-doce, mel e açúcar;

- Requentão: cachaça e café requentado;

- Bate-bate: cachaça, maracujá e mel. 
As festas de caráter regional são Boi-bumbá (Amazonas), Maracatu (Pernambuco), Farra do Boi (Santa Catarina), Bumba meu boi (Maranhão), dentre outras. Ela faz parte não somente da mitologia, mas também do ritual do candomblé e da umbanda. Seu uso em práticas religiosas populares indica que é a bebida mais identificada com o povo brasileiro

Uma coisa para ser folclórica, deve ser aceita e consagrada pelo povo. 


\section{CONSIDERAÇÕES FINAIS}

A cachaça é uma bebida eminentemente brasileira. Sua importância é cultural, econômica e política. Sua descoberta foi por acaso. Surgiu em meio à produção de açúcar em engenhos brasileiros. Ao coar o caldo de cana fervido, os escravos guardavam a espuma em cochos de madeira. Quando fermentava, a nata da cana virava um líquido azedo que servia de alimento para os animais e os próprios escravos.

Depois da descoberta, no início do século XVI, a construção de engenhos tornou-se atrativa a outras Capitanias Hereditárias. No início, os senhores de engenho desdenhavam da bebida. Porém, com o aperfeiçoamento da produção, que passou a ser feita em alambiques de cobre, a cachaça ganhou espaço na Casa Grande. A fama chegou a países da Europa e Ásia. A bebida foi usada como pagamento na compra de escravos.

A Coroa Portuguesa passou a dificultar a produção da cachaça no Brasil, devido apresentar-se como forte concorrente com os vinhos. Pode-se afirmar que a investida contra essa bebida virou símbolo de resistência em movimentos populares, como a Inconfidência Mineira.

Por ser considerada a bebida do povo brasileiro, ela representa mais que um produto econômico. É uma significativa expressão da cultura brasileira, pela sua história e suas relações com as festas populares e o futebol.

Futebol e cachaça estão presentes no cotidiano do brasileiro, na forma das mais variadas manifestações. Com o trabalho de levantamento de informações junto ao grupo inquirido, pôde-se verificar a idéia de associação entre futebol e cachaça, sendo que aquele é uma forma de propiciar as vendas deste, mediante as comemorações envolvidas, de vitória ou de derrota. Infelizmente a concepção dessa relação, geralmente, é de algazarra, o que reforça a idéia de ser consumida pelas classes sociais menos favorecidas.

Como a cachaça industrial preserva a quantidade em detrimento da qualidade, geralmente, é vendida a um preço menor, favorecendo o consumo das 
classes sociais menos abastadas, por sua popularidade e facilidade de consumo, principalmente em festas populares como no carnaval.

Atualmente, a cachaça é exportada para diversos países como Alemanha, Itália, Portugal e Uruguai. No primeiro bimestre do corrente ano, foram vendidas 1.700 toneladas no mercado externo. A tendência verificada é que sejam crescentes essas exportações, fortalecendo a presença da cultura brasileira pelo mundo, mediante 0 produto. Apesar da tendência, o Brasil deve intensificar a internacionalização da cachaça, ganhando novos mercados, firmando a bebida como um produto de valor agregado tipicamente brasileiro. Não obstante, o governo deve procurar incentivar a produção artesanal a fim de agregar qualidade superior, o que trará valorização na imagem do produto, apesar do menor número de produção em comparação à industrial. 


\section{REFERÊNCIAS BIBLIOGRÁFICAS}

ARAÚJO, Bernadete Durães. Folclore - Interiorizando a informação cultural. 1997.

BELLUZO, Rosa; HECK, Marina. Doces Sabores. São Paulo: Stúdio Nobel, 2002. BRUHNS, Heloísa Turini. Futebol, carnaval e capoeira. Editora Papirus.

BUENO, Eduardo. Brasil - Uma história. São Paulo: Ática, 2004.

CALASANS, José. Cachaça, Moça Branca. 2.ed. Bahia: Livraria Progresso, 1951.

CÂMARA, Marcelo. Cachaça Prazer Brasileiro. Rio de Janeiro: Mauad, 2004.

CARVALHO, Murilo; SILVA, Silvestre. Cachaça, uma alegre história brasileira. São Paulo.

CASCUDO, Luis Câmara. Prelúdio da Cachaça. Rio de Janeiro: Coleção Canavieira número 1, 1968.

CRUZ, Carla; RIBEIRO, Uirá. Metodologia Científica - Teoria e Prática. 2.ed. Rio de Janeiro: Editora Axcel Books do Brasil, 2004.

DA MATTA, Roberto. Carnavais, malandros e heróis: Para uma sociologia do dilema brasileiro. Rio de Janeiro: Editora ZAHAR, 1979.

. O que faz o brasil Brasil? Rio de Janeiro: Editora Rocco, 1986.

FEIJÓ, Atnéia; MACIEL, Engels. Cachaça Artesanal do Alambique à Mesa. Rio de Janeiro: SENAC Nacional, 2002.

FENELON, Dea Ribeiro. 50 Textos de História do Brasil. São Paulo: HUCITEC, 1974.

FREYRE, Gilberto. Casa Grande e Senzala. 1992.

ISKANDAR, Jamil Ibrahim. Normas da ABNT. 2.ed. Curitiba: Editora Juruá, 2003.

LARAIA, Roque de Barros. Cultura: um conceito antropológico. 14.ed. Rio de Janeiro: Editora ZAHAR, 2001.

LODY, Raul. Comer é pertencer. Jornal Correio Braziliense, Brasília, 16 jan., 2005. p.30.

LIMA, Cláudia. Tachos e Panelas - Histografia da Alimentação Brasileira. 2.ed. Paraíba: Editora Comunicarte, 1999. 
MAIOR, Mário Souto. Cachaça. Paraíba: Coleção Canavieira número 3, 1970/71. MARTINS, Clerton. Turismo, cultura e identidade. São Paulo: Editora Roca, 2003. ORTIZ, Renato. Cultura brasileira e identidade nacional. 5.ed. São Paulo: Editora Brasiliense, 1994.

PIRES, Fernando; GOMES, Geraldo. Antigos Engenhos de Açúcar no Brasil. Rio de Janeiro: Nova Fronteira, 1994.

RÊGO, José Lins do. Fogo Morto. 57.ed. Rio de Janeiro: José Olympio, 2002.

UCHOA, Maria Lúcia; MACIEL, Engels. Caipirinha. Rio de Janeiro: Casa da Palavra, 2003.

BRASIL. Decreto 8918, de 14 de julho de 1994. Dispõe sobre a padronização, a classificação, o registro, a inspeção, a produção e a fiscalização de bebidas, autoriza a criação da Comissão Intersetorial de Bebidas e dá outras providências.

BRASIL. Decreto 4062, de 21 de dezembro de 2001. Define as expressões "cachaça", "Brasil" e "cachaça do Brasil" como indicações geográficas e dá outras providências.

BRASIL. Decreto 4851, de 02 de outubro de 2003. Altera dispositivos do Regulamento aprovado pelo Decreto no 2.314 , de 4 de setembro de 1997, que dispõe sobre a padronização, a classificação, o registro, a inspeção, a produção e a fiscalização de bebidas.

$<$ http://www.toneis.com.br>, acesso em 07/04/05.

$<$ http://www.ampaq.com.br>, acesso em 05/11/04.

$<$ http://www.jangadabrasil.com.br>, acesso em 07/ 04/05.

<http://www.ufmg.br/centrocultural/quemsomos/patrimonio.htm>,acesso em 11/04/05

$<$ http://www.iphan.gov.br/bens/P.\%20Imaterial/imaterial.htm>, acesso em 11/04/05.

$<$ http://www.chefonline.com.br>, acesso em 06/12/04.

$<$ http://www.desenvolvimento.gov.br>, acesso em 29/03/05.

Revista Gula - maio, 1998:52

Revista Cachaça Magazine, 2003 


\section{APÊNDICE A}

UNB - UNIVERSIDADE DE BRASILIA

Centro de Excelência em Turismo

Curso de Turismo: Turismo, Cultura e Lazer

INSTRUÇÃO:

Para o preenchimento do questionário abaixo, é possível marcar mais de uma alternativa.

Questionário sobre a Importância Cultural da cachaça para o povo brasileiro:

01 - Faixa etária
( ) 18 a 21 anos
( ) 22 a 25 anos
( ) 26 a 30 anos
( ) 31 a 35 anos
( ) 36 a 40 anos
( ) 56 a 60 anos
( ) 61 a 65 anos
( ) Mais de 66 anos
02 - Sexo

( ) Feminino

( ) Masculino

03 - Estado Civil
( ) Solteiro
( ) Desquitado
( ) Casado
( ) Viúvo
( ) Divorciado
( ) Outros

04 - Na sua opinião, a cachaça é um produto obtido através da:
( ) Fermentação da uva
( ) Fermentação do caju
( ) Fermentação da cana-de-açúcar
( ) Fermentação da pêra

05 - Os principais consumidores da cachaça são:
( ) Classe alta
( ) Classe média
( ) Classe media alta
( ) Classe baixa

06 - Você aprecia cachaça, seja pura ou em suas formas derivadas, como, caipirinha, batidas e coquetéis?
( ) Sim
( ) Não

07 - Para você, o consumo desde produto é:
( ) Diário
( ) Semanal
( ) Mensal
( ) Ocasional

08 - Na sua opinião, a cachaça é consumida / usada:
( ) Em festas populares
( ) Em cerimônias religiosas
( ) Em receitas de pratos típicos
( ) Na medicina
( ) Em eventos de grande porte
( ) Antes das refeições
( ) Após o expediente de trabalho

09 - Você acha que a cachaça pode ser considerada um elemento da Cultura Nacional? Por que? 10 - Você associa de alguma forma a cachaça ao futebol e ao carnaval? Como?

11- Na sua opinião, a cachaça alcançará respeito internacional? Por que? 


\section{APÊNDICE B}

\section{Item A - Características dos Informantes}
A.1 SEXO
A.1.1 Masculino
A.1.2 Feminino

A.2 FAIXA ETÁRIA

A.2.1 21 a 25 anos

A.2.2 26 a 30 anos

A.2.3 31 a 35 anos

A.2.4 36 a 40 anos

A.2.5 41 a 45 anos

A.2.6 46 a 50 anos

A.2.7 51 a 55 anos
A.3 ESTADO CIVIL
A.3.1 Solteiro
A.3.2 Casado
A.3.3 Divorciado

\section{Item B - Indagações sobre cachaça}

B.1 A Cachaça é obtida através da:

B.1.1 Fermentação da uva

B.1.2 Fermentação da cana-de-açúcar

B.1.3 Fermentação do caju

B.1.4 Fermentação da pêra

B.2 Principais consumidores:

B.2.1 Classe baixa

B.2.2 Classe média

B.2.3 Classe média-alta

B.2.4 Classe alta

B.3 Aprecia cachaça e seus derivados?

B.3.1 Sim

B.3.2 Não

B.4 O consumo geralmente é:

B.4.1 Ocasional

B.4.2 Semanal

B.4.3 Mensal

B.5 A cachaça é consumida/usada:

B.5.1 Em festas populares

B.5.2 Em cerimônias religiosas

B.5.3 Em receitas de pratos típicos

B.5.4 Na medicina

B.5.5 Em eventos de grande porte

B.5.6 Antes das refeições

B.5.7 Após o expediente de trabalho

B.6 Pode ser considerada um elemento da cultura nacional?

B.6.1 Sim

B.6.2 Não

B.7 Você a associa ao futebol e ao carnaval?

B.7.1 Sim

B.7.2 Não

B.8.1 Sim

B.8.2 Não
A cachaça alcançará respeito internacional? 


\section{APÊNDICE C}

Tabulação do questionário

\begin{tabular}{|c|c|c|c|c|c|c|c|c|c|c|c|c|}
\hline \multicolumn{13}{|c|}{ Folha-sumário } \\
\hline \multicolumn{13}{|c|}{ ITEM A } \\
\hline & \multicolumn{2}{|c|}{ A.1 } & \multicolumn{7}{|c|}{ A.2 } & \multicolumn{3}{|c|}{ A.3 } \\
\hline & A.1.1 & A.1.2 & A.2.1 & A.2.2 & A.2.3 & A.2.4 & A.2.5 & A.2.6 & A.2.7 & A.3.1 & A.3.2 & A.3.3 \\
\hline 1 & & $x$ & & $x$ & & & & & & & $x$ & \\
\hline 2 & $x$ & & & & & & $x$ & & & & $x$ & \\
\hline 3 & & $x$ & & & & & & & $x$ & & $x$ & \\
\hline 4 & & $x$ & & & & & $x$ & & & & $x$ & \\
\hline 5 & $x$ & & $x$ & & & & & & & $x$ & & \\
\hline 6 & $x$ & & & & & $x$ & & & & & & $x$ \\
\hline 7 & & $x$ & & & & & & & $x$ & & $x$ & \\
\hline 8 & & $x$ & & & & & & $x$ & & & $x$ & \\
\hline 9 & $x$ & & $x$ & & & & & & & $x$ & & \\
\hline 10 & $x$ & & & & & & $x$ & & & & $x$ & \\
\hline 11 & $x$ & & & $x$ & & & & & & & $x$ & \\
\hline 12 & & $x$ & $x$ & & & & & & & $x$ & & \\
\hline 13 & & $x$ & & $x$ & & & & & & & $x$ & \\
\hline 14 & $x$ & & & & $x$ & & & & & & & $x$ \\
\hline 15 & & $x$ & & & & & & & $x$ & & $x$ & \\
\hline 16 & & $x$ & $x$ & & & & & & & $x$ & & \\
\hline 17 & & $x$ & & & & & & $x$ & & & $x$ & \\
\hline 18 & & $x$ & $x$ & & & & & & & $x$ & & \\
\hline 19 & $x$ & & $x$ & & & & & & & $x$ & & \\
\hline 20 & & $x$ & & $x$ & & & & & & $x$ & & \\
\hline 21 & & $x$ & $x$ & & & & & & & $x$ & & \\
\hline 22 & & $x$ & & & & & $x$ & & & & & $x$ \\
\hline 23 & $x$ & & & & & & & & $x$ & & & $x$ \\
\hline Total & 9 & 14 & 7 & 4 & 1 & 1 & 4 & 2 & 4 & 8 & 11 & 4 \\
\hline
\end{tabular}

masculino feminino 
Tabulação do questionário

Folha-sumário

\begin{tabular}{|c|c|c|c|c|c|c|c|c|c|c|c|c|c|c|c|c|c|c|c|c|c|c|c|c|c|c|}
\hline \multicolumn{27}{|c|}{ Folha-sumário } \\
\hline \multicolumn{27}{|c|}{ ITEM B } \\
\hline & \multicolumn{4}{|c|}{ B.1 } & \multicolumn{4}{|c|}{ B. 2} & \multicolumn{2}{|c|}{ B. 3} & \multicolumn{3}{|c|}{ B.4 } & \multicolumn{7}{|c|}{ B. 5} & \multicolumn{2}{|c|}{ B. 6} & \multicolumn{2}{|c|}{ B. 7} & \multicolumn{2}{|c|}{ B. 8} \\
\hline & B.1.1 & B.1.2 & B.1.3 & B.1.4 & B.2.1 & B.2.2 & B.2.3 & B.2.4 & B.3.1 & B.3.2 & B.4.1 & B.4.2 & \begin{tabular}{|l} 
B.4.3. \\
\end{tabular} & B.5.1 & B.5.2 & B.5.3 & B.5.4 & B.5.5 & B.5.6 & B.5.7 & B.6.1 & \begin{tabular}{|l|} 
\\
\end{tabular} & B.7.1 & B.7.2 & B.8.1 & B.8.2 \\
\hline 1 & & $x$ & $x$ & & $x$ & & & & $x$ & & $x$ & & & $x$ & & $x$ & & & $x$ & $x$ & $x$ & & $x$ & & $x$ & \\
\hline 2 & $x$ & $x$ & $x$ & $x$ & $x$ & & & & & $x$ & $x$ & & & $x$ & & & & & & & $x$ & & $x$ & & $x$ & \\
\hline 3 & & $x$ & & & $x$ & & $\mathrm{x}$ & & $\mathrm{x}$ & & $x$ & & & $\mathrm{x}$ & & $\mathrm{x}$ & & & & $x$ & $\mathrm{x}$ & & $x$ & & $x$ & \\
\hline 4 & & $x$ & & & $x$ & & & & & $\mathrm{x}$ & & $\mathrm{x}$ & & $\mathrm{x}$ & & & & & & & $\mathrm{x}$ & & & $\mathrm{x}$ & $x$ & \\
\hline 5 & & $x$ & & & & $x$ & $x$ & & $\mathrm{x}$ & & $\mathrm{x}$ & & & & & & & & $x$ & $x$ & $x$ & & & $x$ & $\mathrm{x}$ & \\
\hline 6 & & $x$ & & & $x$ & & & & $\mathrm{x}$ & & $\mathrm{x}$ & & & $\mathrm{x}$ & & & & & & & $\mathrm{x}$ & & $\mathrm{x}$ & & $x$ & \\
\hline 7 & & $x$ & & & $\mathrm{x}$ & $\mathrm{x}$ & $\mathrm{x}$ & & $\mathrm{x}$ & & $x$ & & & $\mathrm{x}$ & $\mathrm{x}$ & $\mathrm{x}$ & & & $\mathrm{x}$ & & $\mathrm{x}$ & & & $\mathrm{x}$ & $\mathrm{x}$ & \\
\hline 8 & $x$ & $x$ & $x$ & $x$ & $x$ & & & & $\mathrm{x}$ & & $x$ & & & $\mathrm{x}$ & & & $x$ & & & $x$ & $\mathrm{x}$ & & & $\mathrm{x}$ & $\mathrm{x}$ & \\
\hline 9 & & $\mathrm{x}$ & & & $\mathrm{x}$ & & & & $\mathrm{x}$ & & $x$ & & & $\mathrm{x}$ & $x$ & $x$ & $x$ & $\mathrm{x}$ & $x$ & $x$ & $\mathrm{x}$ & & & $\mathrm{x}$ & $x$ & \\
\hline 10 & & $x$ & & & & $x$ & & & $\mathrm{x}$ & & $x$ & & & & & & & & $x$ & & $x$ & & & $\mathrm{x}$ & $x$ & \\
\hline 11 & & $x$ & & & $x$ & $x$ & & & $\mathrm{x}$ & & $x$ & & & $x$ & & & & & & $x$ & $x$ & & $x$ & & $x$ & \\
\hline 12 & & $x$ & & & $x$ & & & & & $x$ & $x$ & & & & & & & & $x$ & & $x$ & & $\mathrm{x}$ & & $x$ & \\
\hline 13 & & $x$ & & & $x$ & & & & $x$ & & $x$ & & & $x$ & & & & & & & $x$ & & $x$ & & $x$ & \\
\hline 14 & & $x$ & & & $x$ & & & & $x$ & & & & $x$ & $x$ & $x$ & & & & & $x$ & $x$ & & $x$ & & & $x$ \\
\hline 15 & & $x$ & & & $x$ & & & & & $x$ & $x$ & & & & & & & & $x$ & & $x$ & & $x$ & & $\mathrm{x}$ & \\
\hline 16 & & $x$ & & & & & $x$ & & & $x$ & $x$ & & & $x$ & & $x$ & & $x$ & $x$ & $x$ & $x$ & & $x$ & & $x$ & \\
\hline 17 & & $x$ & & & $x$ & & & & & $x$ & $x$ & & & $x$ & & & & & & & $x$ & & $x$ & & $x$ & \\
\hline 18 & & $\mathrm{x}$ & & & $x$ & & $x$ & & $\mathrm{x}$ & & $x$ & & & $x$ & & & & & & & $x$ & & & $x$ & $x$ & \\
\hline 19 & & $x$ & & & $x$ & & $\mathrm{x}$ & & $x$ & & $x$ & & & $x$ & & & & & $x$ & & $x$ & & $x$ & & $x$ & \\
\hline 20 & & $x$ & & & $x$ & $x$ & $x$ & $x$ & $x$ & & $x$ & & & $x$ & & $x$ & & & $x$ & $x$ & $x$ & & & $x$ & $x$ & \\
\hline 21 & & $x$ & & & $x$ & & & & & $x$ & $x$ & & & $x$ & & & & & & & $x$ & & $x$ & & $x$ & \\
\hline 22 & & $x$ & & & $x$ & & & & & $x$ & $x$ & & & $x$ & & $x$ & & & & & $x$ & & & $x$ & $x$ & \\
\hline 23 & $x$ & $x$ & $x$ & $x$ & $x$ & & & & $\mathrm{X}$ & & $x$ & & & & & & & & $x$ & & $x$ & & $x$ & & $x$ & \\
\hline Total & 3 & 23 & 4 & 3 & 20 & 5 & 7 & 1 & 15 & 8 & 21 & 1 & 1 & 18 & 3 & 7 & 2 & 2 & 11 & 9 & 23 & 0 & 14 & 9 & 22 & 1 \\
\hline
\end{tabular}

masculino

feminino 


\section{Presidência da República Subchefia para Assuntos Jurídicos}

\section{LEI Nº 8.918, DE 14 DE JULHO DE 1994.}

Dispõe sobre a padronização, a classificação, o registro, a inspeção, a

$\underline{\text { Regulamento }}$ produção e a fiscalização de bebidas, autoriza a criação da Comissão Intersetorial de Bebidas e dá outras providências.

O PRESIDENTE DA REPÚBLICA Faço saber que o Congresso Nacional decreta e eu sanciono a seguinte lei:

Art. $1^{\circ}$ É estabelecida, em todo o território nacional, a obrigatoriedade do registro, da padronização, da classificação, da inspeção e da fiscalização da produção e do comércio de bebidas.

Parágrafo único. A inspeção e a fiscalização de que trata esta lei incidirão sobre:

I - Inspeção:

a) equipamentos e instalações, sob os aspectos higiênicos, sanitários e técnicos;

b) embalagens, matérias-primas e demais substâncias, sob os aspectos higiênicos, sanitários e qualitativos;

II - Fiscalização;

a) estabelecimentos que se dediquem à industrialização, à exportação e à importação dos produtos objeto desta lei;

b) portos, aeroportos e postos de fronteiras;

c) transporte, armazenagem, depósito, cooperativa e casa atacadista; e

d) quaisquer outros locais previstos na regulamentação desta lei.

Art. $2^{\circ} \mathrm{O}$ registro, a padronização, a classificação, e, ainda, a inspeção e a fiscalização da produção e do comércio de bebidas, em relação aos seus aspectos tecnológicos, competem ao Ministério da Agricultura, do Abastecimento e da Reforma Agrária.

Art. $3^{\circ} \mathrm{A}$ inspeção e a fiscalização de bebidas, nos seus aspectos bromatológicos e sanitários, são da competência do Sistema Único de Saúde (SUS), por intermédio de seus órgãos específicos.

Art. $4^{\circ}$ Os estabelecimentos que industrializem ou importem bebidas ou que as comercializem a granel só poderão fazê-lo se obedecerem, em seus equipamentos e instalações, bem como em seus produtos, aos padrões de identidade e qualidade fixados para cada caso. 
Parágrafo único. As bebidas de procedência estrangeira somente poderão ser objeto de comércio ou entregues ao consumo quando suas especificações atenderem aos padrões de identidade e qualidade previstos para os produtos nacionais, excetuados os produtos que tenham características peculiares e cuja comercialização seja autorizada no país de origem.

Art. $5^{\circ}$ Suco ou sumo é bebida não fermentada, não concentrada e não diluída, obtida da fruta madura e sã, ou parte do vegetal de origem, por processamento tecnológico adequado, submetida a tratamento que assegure a sua apresentação e conservação até o momento do consumo.

$\S 1^{\circ} \mathrm{O}$ suco não poderá conter substâncias estranhas à fruta ou parte do vegetal de sua origem, excetuadas as previstas na legislação específica.

$\S 2^{\circ}$ No rótulo da embalagem ou vasilhame do suco será mencionado o nome da fruta, ou parte do vegetal, de sua origem.

$\S 3^{\circ} \mathrm{O}$ suco que for parcialmente desidratado deverá mencionar no rótulo o percentual de sua concentração, devendo ser denominado suco concentrado.

$\S 4^{\circ}$ Ao suco poderá ser adicionado açúcar na quantidade máxima de dez por cento em peso, devendo constar no rótulo a declaração suco adoçado.

$\S 5^{\circ}$ É proibida a adição, em sucos, de aromas e corantes artificiais.

Art. $6^{\circ}$ A bebida conterá, obrigatoriamente, a matéria-prima natural responsável pelas suas características organolépticas, obedecendo aos padrões de identidade e qualidade previstos em regulamento próprio.

$\S 1^{\circ}$ As bebidas que não atenderem ao disposto no caput deste artigo serão denominadas artificiais e deverão observar as disposições regulamentares desta lei.

$\S 2^{\circ}$ As bebidas que apresentarem características organolépticas próprias de matéria-prima natural de sua origem, ou cujo nome ou marca se lhe assemelhe, conterão, obrigatoriamente, esta matéria-prima nas quantidades a serem estabelecidas na regulamentação desta lei.

Art. $7^{\circ}$ As bebidas dietéticas e de baixa caloria poderão ser industrializadas observadas as disposições desta lei, do seu regulamento e legislação complementar, permitido o emprego de edulcorantes naturais e sintéticos na sua elaboração.

$\S 1^{\circ} \mathrm{Na}$ industrialização de bebidas dietéticas e de baixa caloria, poderão ser feitas associações entre edulcorantes naturais e sintéticos, obedecido o disposto na regulamentação desta lei.

$\S 2^{\circ} \mathrm{Na}$ rotulagem de bebida dietética e de baixa caloria, além dos dizeres a serem estabelecidos na regulamentação desta lei, deverá constar o nome genérico do edulcorante, ou edulcorantes, quando houver associação, sua classe e quantidade ou peso por unidade.

$\S 3^{\circ}$ É livre a comercialização, em todo o território nacional, das bebidas dietéticas e de baixa caloria, observadas as disposições desta lei.

Art. $8^{\circ}$ É facultado o uso da denominação conhaque, seguida da especificação das ervas aromáticas ou componentes outros empregados como substância principal do produto destilado alcoólico que, na sua elaboração, não aproveite como matéria-prima o destilado ou aguardente vínica.

Art. $9^{\circ}$ Sem prejuízo da responsabilidade civil e penal cabível, a infração das disposições desta lei acarretará, isolada ou cumulativamente, nos termos previstos em regulamento, além das medidas cautelares de fechamento do estabelecimento, apreensão e destinação da matéria-prima, produto ou equipamento, as seguintes sanções administrativas: 
I - advertência;

II - (Vetado).

III - inutilização da matéria-prima, rótulo e/ou produto;

IV - interdição do estabelecimento ou equipamento;

V - suspensão da fabricação do produto; e

VI - cassação da autorização para funcionamento do estabelecimento cumulada ou não com a proibição de venda e publicidade do produto.

Art. 10. Na aplicação das medidas cautelares ou do auto de infração, haverá nomeação de um depositário idôneo.

Parágrafo único. (Vetado).

Art. 11. O Poder Executivo fixará em regulamento, além de outras providências, as disposições específicas referentes à classificação, padronização, rotulagem, análise de produtos, matériasprimas, inspeção e fiscalização de equipamentos, instalações e condições higiênico-sanitárias dos estabelecimentos industriais, artesanais e caseiros, assim como a inspeção da produção e a fiscalização do comércio de que trata esta lei.

Art. 12. (Vetado).

Art. 13. O Poder Executivo regulamentará esta lei no prazo de cento e oitenta dias, contados de sua publicação.

Art. 14. Esta lei entra em vigor na data de sua publicação.

Art. 15. Revogam-se as disposições em contrário, em especial a Lei $n^{0} 5.823$, de 14 de novembro de 1972.

Brasília, 14 de julho de 1994; $173^{\circ}$ da Independência e $106^{\circ}$ da República.

ITAMAR FRANCO

Synval Guazzelli

Henrique Santillo

Este texto não substitui o publicado no D.O.U de 15.7.1994 


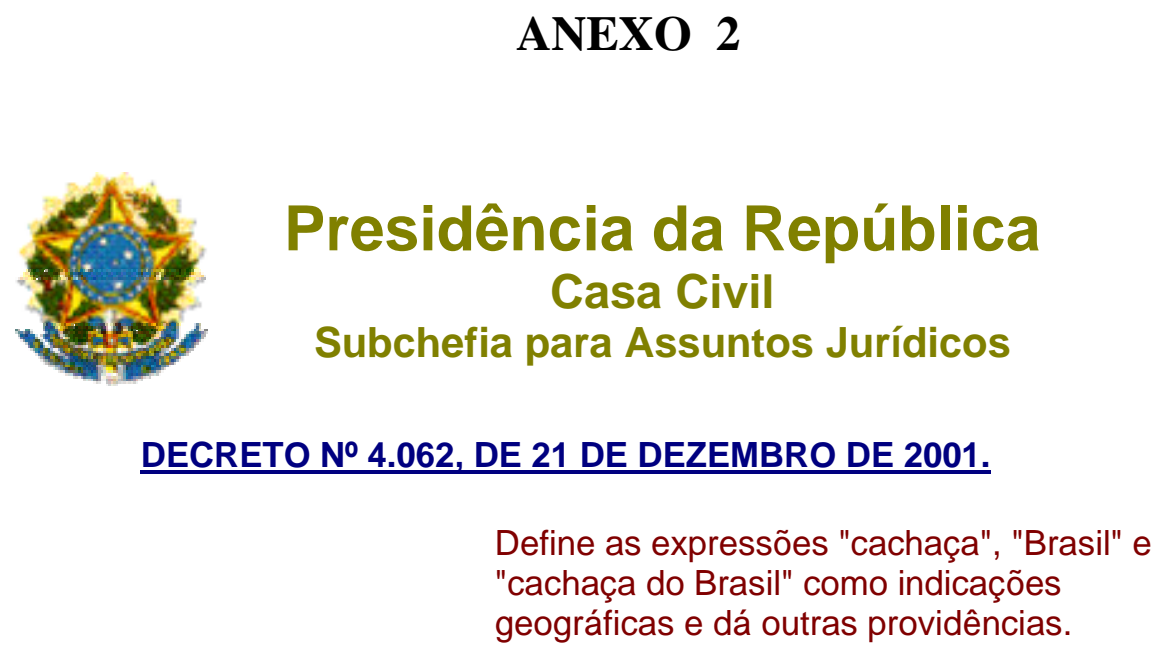

O PRESIDENTE DA REPÚBLICA, no uso da atribuição que lhe confere o art. 84, inciso IV, da Constituição, e tendo em vista o disposto no art. 22 do Acordo sobre Aspectos dos Direitos de Propriedade Intelectual relacionados ao Comércio, aprovado, como parte integrante do Acordo de Marraqueche, pelo Decreto Legislativo $\mathrm{n}^{-0}$ 30, de 15 de dezembro de 1994, e promulgado pelo Decreto $n^{-}$1.355, de 30 de dezembro de 1994, e nos arts. 176 a 182 da Lei $n^{0}$ 9.279, de 14 de maio de 1996,

\section{DECRETA:}

Art. 1ํำ nome "cachaça", vocábulo de origem e uso exclusivamente brasileiros, constitui indicação geográfica para os efeitos, no comércio internacional, do art. 22 do Acordo sobre Aspectos dos Direitos de Propriedade Intelectual relacionados ao Comércio, aprovado, como parte integrante do Acordo de Marraqueche, pelo Decreto Legislativo no 30, de 15 de dezembro de 1994, e promulgado pelo Decreto $n^{0} 1.355$, de 30 de dezembro de 1994.

Art. $2^{0}$ O nome geográfico "Brasil" constitui indicação geográfica para cachaça, para os efeitos da Lei $n^{\circ} 9.279$, de 14 de maio de 1996, e para os efeitos, no comércio internacional, do art. 22 do Acordo a que se refere 0 art. $1^{\circ}$.

Parágrafo único. O nome geográfico "Brasil" poderá se constituir em indicação geográfica para outros produtos e serviços a serem definidos em ato do Poder Executivo.

Art. $3^{0}$ As expressões protegidas "cachaça", "Brasil" e "cachaça do Brasil" somente poderão ser usadas para indicar o produto que atenda às regras gerais estabelecidas na Lei $n^{0} 8.918$, de 14 de julho de 1994, e no Decreto $n^{0} 2.314$, de 4 de setembro de 1997, e nas demais normas específicas aplicáveis.

$\S 1^{\text {o }}$ O uso das expressões protegidas "cachaça", "Brasil" e "cachaça do Brasil" é restrito aos produtores estabelecidos no País.

$\S 2^{\underline{0}}$ O produtor de cachaça que, por qualquer meio, usar as expressões protegidas por este Decreto em desacordo com este artigo perderá o direito de usá-la em seus produtos e em quaisquer meios de divulgação.

Art. 4ํ A Câmara de Comércio Exterior aprovará o Regulamento de Uso das Indicações Geográficas previstas neste Decreto de acordo com critérios técnicos definidos pelos Ministérios do Desenvolvimento, Indústria e Comércio Exterior e da Agricultura, Pecuária e Abastecimento, no âmbito de suas respectivas competências.

Art. $5^{\circ}$ Este Decreto entra em vigor na data de sua publicação. 
Brasília, 21 de dezembro de 2001; 180ํํㅁ Independência e 113ํำ da República.

FERNANDO HENRIQUE CARDOSO

Sérgio Silva do Amaral

Este texto não substitui o publicado no D.O.U. 26.12.2001 
ANEXO 3

\section{1* Presidência da República \\ Casa Civil \\ Subchefia para Assuntos Jurídicos}

DECRETO № 4.851, DE 2 DE OUTUBRO DE 2003.

Altera dispositivos do Regulamento aprovado pelo Decreto $\mathrm{n}^{\circ}$ 2.314, de 4 de setembro de 1997, que dispõe sobre a padronização, a classificação, o registro, a inspeção, a produção e a fiscalização de bebidas.

O PRESIDENTE DA REPÚBLICA, no uso da atribuição que the confere o art. 84, inciso IV, da Constituição,

\section{DECRETA:}

Art. $1^{\circ}$ O Regulamento aprovado pelo Decreto $\mathrm{n}^{\circ}$ 2.314, de 4 de setembro de 1997, passa a vigorar com as seguintes alterações:

"Art. 81.

$\S 4^{\circ}$ Caipirinha é a bebida típica brasileira, com graduação alcoólica de quinze a trinta e seis por cento em volume, a vinte graus Celsius, obtida exclusivamente com Cachaça, acrescida de limão e açúcar.

§ $5^{\circ}$ O limão de que trata o $\S 4^{0}$ deste artigo, poderá ser adicionado na forma desidratada." (NR)

"Art. 90.

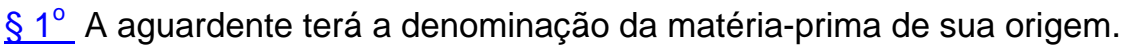

$\S 2^{\circ}$ Aguardente de melaço é a bebida com graduação alcoólica de trinta e oito a cinqüenta e quatro por cento em volume, a vinte graus Celsius, obtida do destilado alcoólico simples de melaço ou, ainda, pela destilação do mosto fermentado de melaço, podendo ser adoçada e envelhecida, cujo coeficiente de congênere será definido em ato administrativo complementar.

$\S 3^{\circ}$ Aguardente de cereal é a bebida com graduação alcoólica de trinta e oito a cinqüenta e quatro por cento em volume, a vinte graus Celsius, obtida do destilado alcoólico simples de cereal ou pela destilação do mosto fermentado de cereal, podendo ser adoçada e envelhecida, cujo coeficiente de congênere será definido em ato administrativo complementar.

$\S 4^{\circ}$ Aguardente de vegetal é a bebida com graduação alcoólica de trinta e oito a cinqüenta e quatro por cento em volume, a vinte graus Celsius, obtida do destilado alcoólico simples de vegetal ou pela destilação do mosto fermentado de vegetal, podendo ser adoçada e envelhecida, cujo coeficiente de congênere será definido em ato administrativo complementar. 
$\S 5^{\circ}$ Aguardente de rapadura ou melado é a bebida com graduação alcoólica de trinta e oito a cinqüenta e quatro por cento em volume, a vinte graus Celsius, obtida do destilado alcoólico simples de rapadura ou melado ou pela destilação do mosto fermentado de rapadura ou melado, podendo ser adoçada e envelhecida, cujo coeficiente de congênere será definido em ato administrativo complementar."(NR)

"Art. 91. Aguardente de cana é a bebida com graduação alcoólica de trinta e oito a cinqüenta e quatro por cento em volume, a vinte graus Celsius, obtida de destilado alcoólico simples de cana-deaçúcar ou pela destilação do mosto fermentado de cana-de-açúcar, podendo ser adicionada de açúcares até seis gramas por litro.

$\S 1^{\circ}$ A bebida que contiver açúcares em quantidade superior a seis e inferior a trinta gramas por litro será denominada aguardente de cana adoçada.

$\S 2^{\circ}$ Será denominada aguardente de cana envelhecida a bebida que contiver no mínimo cinqüenta por cento de aguardente de cana envelhecida, por um período não inferior a um ano, podendo ser adicionada de caramelo para a correção da cor.

$\S 3^{\circ} \mathrm{O}$ coeficiente de congêneres da aguardente de cana não poderá ser inferior a duzentos miligramas por cem mililitros de álcool anidro."(NR)

"Art. 92. Cachaça é a denominação típica e exclusiva da aguardente de cana produzida no Brasil, com graduação alcoólica de trinta e oito a quarenta e oito por cento em volume, a vinte graus Celsius, obtida pela destilação do mosto fermentado de cana-de-açúcar com características sensoriais peculiares, podendo ser adicionada de açúcares até seis gramas por litro, expressos em sacarose.

$\S 1^{\circ} \mathrm{A}$ cachaça que contiver açúcares em quantidade superior a seis e inferior a trinta gramas por litro será denominada cachaça adoçada.

$\S 2^{\circ}$ Será denominada de cachaça envelhecida, a bebida que contiver no mínimo cinqüenta por cento de aguardente de cana envelhecida, por um período não inferior a um ano, podendo ser adicionada de caramelo para a correção da cor.

$\S 3^{\circ} \mathrm{O}$ coeficiente de congêneres da cachaça não poderá ser inferior a duzentos miligramas por cem mililitros de álcool anidro."(NR)

"Art. 93. Rum, rhum ou ron é a bebida com a graduação alcoólica de trinta e cinco a cinqüenta e quatro por cento em volume, a vinte graus Celsius, obtida do destilado alcoólico simples de melaço, ou da mistura dos destilados de caldo de cana-de-açúcar e de melaço, envelhecidos, total ou parcialmente, em recipiente de carvalho ou madeira equivalente, conservando suas características sensoriais peculiares.

$\S 1^{0} \mathrm{O}$ produto poderá ser adicionado de açúcares até uma quantidade máxima de seis gramas por litro.

$\underline{\S 2^{0}}$ Será permitido o uso de caramelo para correção da cor e carvão ativado para a descoloração.

$\S 3^{\circ} \mathrm{O}$ coeficiente de congêneres não poderá ser inferior a quarenta miligramas e nem superior a quinhentos miligramas por cem mililitros de álcool anidro.

$\underline{\S 4^{\circ}}$ O rum poderá denominar-se:

I- rum leve (light rum) quando o coeficiente de congêneres da bebida for inferior a duzentos miligramas por cem mililitros em álcool anidro;

II - rum pesado (heavy rum) quando o coeficiente de congêneres da bebida for de duzentos a quinhentos miligramas por cem mililitros em álcool anidro, obtido exclusivamente do melaço; e 
III - rum envelhecido ou rum velho é a bebida que tenha sido envelhecida, em sua totalidade, por um período mínimo de dois anos."(NR)

Art. $2^{\circ}$ O Regulamento aprovado pelo Decreto $\mathrm{n}^{\circ} 2.314$, de 1997, deverá ser republicado com as modificações introduzidas por este Decreto.

Art. $3^{0}$ Este Decreto entra em vigor na data de sua publicação.

Art. $4^{0}$ Fica revogado o Decreto $\mathrm{n}^{0} 4.072$, de 3 de janeiro de 2002.

Brasília, 2 de outubro de 2003; 182ㅇ da Independência e 115o da República.

LUIZ INÁCIO LULA DA SILVA

José Amauri Dimarzio

Este texto não substitui o publicado no D.O.U. de 3.10.2003 